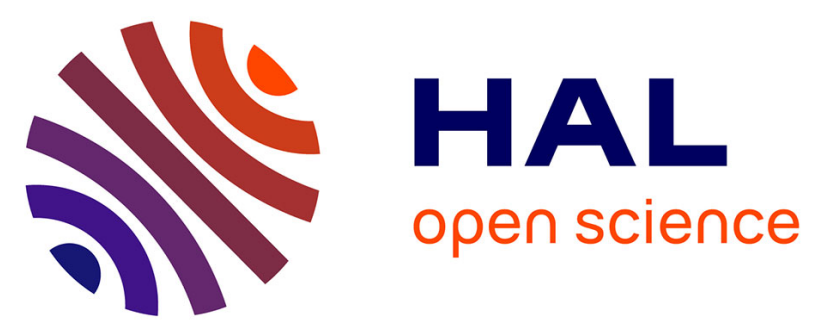

\title{
Annealing tests of in-pile irradiated oxide coated U-Mo/Al-Si dispersed nuclear fuel
}

T. Zweifel, Ch. Valot, Yves Pontillon, J. Lamontagne, A. Vermersch, Laurent Barrallier, T. Blay, W. Petry, H. Palancher

\section{- To cite this version:}

T. Zweifel, Ch. Valot, Yves Pontillon, J. Lamontagne, A. Vermersch, et al.. Annealing tests of in-pile irradiated oxide coated U-Mo/Al-Si dispersed nuclear fuel. Journal of Nuclear Materials, 2014, 452 (1-3), pp.533-547. 10.1016/j.jnucmat.2014.05.052 . hal-01021884

\section{HAL Id: hal-01021884 \\ https://hal.science/hal-01021884}

Submitted on 30 Aug 2017

HAL is a multi-disciplinary open access archive for the deposit and dissemination of scientific research documents, whether they are published or not. The documents may come from teaching and research institutions in France or abroad, or from public or private research centers.
L'archive ouverte pluridisciplinaire HAL, est destinée au dépôt et à la diffusion de documents scientifiques de niveau recherche, publiés ou non, émanant des établissements d'enseignement et de recherche français ou étrangers, des laboratoires publics ou privés. 


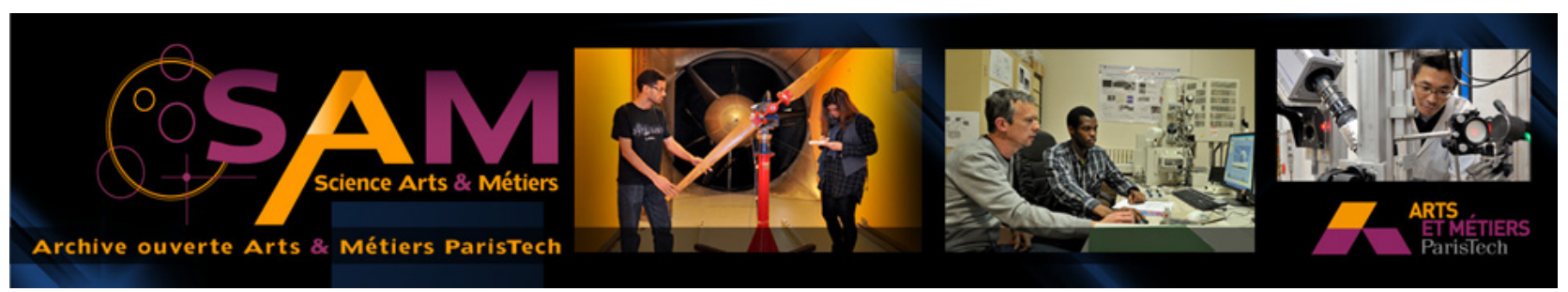

\section{Science Arts \& Métiers (SAM)}

is an open access repository that collects the work of Arts et Métiers ParisTech researchers and makes it freely available over the web where possible.

This is an author-deposited version published in: http://sam.ensam.eu

Handle ID: .http://hdl.handle.net/10985/8337

\section{To cite this version :}

T. ZWEIFEL, Ch. VALOT, Y. PONTILLON, J. LAMONTAGNE, A. VERMERSCH, Laurent BARRALLIER, T. BLAY, W. PETRY, H. PALANCHER - Annealing tests of in-pile irradiated oxide coated U-Mo/Al-Si dispersed nuclear fuel - Journal of Nuclear Materials - Vol. 452, $n^{\circ} 1-3, p .533-$ $547-2014$ 


\title{
Annealing tests of in-pile irradiated oxide coated U-Mo/Al-Si dispersed nuclear fuel
}

\author{
T. Zweifel ${ }^{\mathrm{a}, \mathrm{b}}$, Ch. Valot ${ }^{\mathrm{a}}$, Y. Pontillon ${ }^{\mathrm{a}}$, J. Lamontagne ${ }^{\mathrm{a}}$, A. Vermersch ${ }^{\mathrm{c}}$, L. Barrallier $^{\mathrm{c}}$, T. Blay ${ }^{\mathrm{a}}$, W. Petry ${ }^{\mathrm{b}}$, \\ H. Palancher ${ }^{\mathrm{a}, *}$ \\ ${ }^{a}$ CEA, DEN, DEC, F-13108 St. Paul Lez Durance Cedex, France \\ ${ }^{\mathrm{b}}$ Forschungsneutronenquelle Heinz Maier-Leibniz (FRM II), Technische Universität München Lichtenbergstr. 1, D-85747 Garching, Germany \\ ${ }^{\mathrm{c}}$ MSMP, ENSAM, Aix en Provence, France
}

\begin{abstract}
A B S T R A C T
$\mathrm{U}-\mathrm{Mo} / \mathrm{Al}$ based nuclear fuels have been worldwide considered as a promising high density fuel for the conversion of high flux research reactors from highly enriched uranium to lower enrichment. In this paper, we present the annealing test up to $1800^{\circ} \mathrm{C}$ of in-pile irradiated U-Mo/Al-Si fuel plate samples. More than $70 \%$ of the fission gases (FGs) are released during two major FG release peaks around $500{ }^{\circ} \mathrm{C}$ and $670^{\circ} \mathrm{C}$. Additional characterisations of the samples by XRD, EPMA and SEM suggest that up to $500{ }^{\circ} \mathrm{C} \mathrm{FGs}$ are released from IDL/matrix interfaces. The second peak at $670^{\circ} \mathrm{C}$ representing the main release of FGs originates from the interaction between $\mathrm{U}-\mathrm{Mo}$ and matrix in the vicinity of the cladding.
\end{abstract}

\section{Introduction}

Research and test reactors worldwide are preparing to convert their operation from fuels with high uranium enrichment towards fuels of lower enrichment. For the most powerful reactors, this conversion without loss of performance (i.e. high neutron flux) implies the design of a new high density fuel. An alloy of uraniummolybdenum (U-Mo with 7 to 10 wt.\% Mo) dispersed in an Al matrix is the most promising candidate for these envisaged high density fuels [1]. The mixture of U-Mo powder particles inside the Al matrix is often called the "meat" and is additionally enclosed by an $\mathrm{Al}$ cladding. Together, the meat and the cladding form the fuel plate.

However, during in-pile test irradiations, the growth of an interdiffusion layer (IDL) between the U-Mo fuel particles and the surrounding Al matrix strongly limits the performance of this fuel $[2,3]$. This IDL has been characterised by scanning electron microscopy (SEM), neutron diffraction, electron probe micro-analysis (EPMA) and transmission electron microscopy (TEM) [4-9]. It has been proposed that these IDLs, which are amorphous for irradiation temperatures below $200{ }^{\circ} \mathrm{C}$, exhibit a poor retention for fission gases (FG) (i.e. Xe). These gases eventually accumulate at the IDL/ Al interfaces in large bubbles of more than $10 \mu \mathrm{m}$ in diameter $[6,7]$. Thus, one major goal of $\mathrm{U}-\mathrm{Mo} / \mathrm{Al}$ development is to understand this fission gas behaviour. The approach chosen for this work consists in combining in situ monitoring of FG release during

\footnotetext{
* Corresponding author. Tel.: +33 4422575 55; fax: +33 4423285

E-mail address: herve.palancher@cea.fr (H. Palancher).
}

thermal treatments with destructive examinations of the annealed samples [10]. This methodology is aimed at defining the initial location of fission gas inside the fuel material and understanding their behaviour.

Samples taken from the IRIS4 in-pile experiment have been selected for this study [11]. In these fuels, U-Mo particles were coated with an oxide layer. The aim of this diffusion barrier was to prevent or at least slow down $\mathrm{U}-\mathrm{Mo} / \mathrm{Al}$ interaction layer growth under in-pile irradiation $[12,13]$. The matrix was either pure $\mathrm{Al}$ or $\mathrm{Al}$ with a $\mathrm{Si}$ addition (Al-Si). The first goal of the IRIS4 experiment was to evaluate the interest of this "oxide" solution, and the second was to check whether this potentially beneficial effect could be cumulated with the well-established influence of $\mathrm{Si}$ addition to the Al matrix [14-19].

In this paper, after having recalled the characteristics of the IRIS4 fuel plates before and after irradiation, the conditions of the thermal treatments and the used instrumentation are detailed. Then, the measured FG release curves are described and the corresponding microstructural changes in the annealed samples are presented. Finally, a discussion about FG behaviour inside the fuel is proposed.

\section{Examinations before thermal treatments}

\subsection{IRIS 4 fuel plate manufacturing and fresh fuel plate} characterisation

U-7 wt.\% Mo particles (enrichment $<20 \mathrm{wt} . \%{ }^{235} \mathrm{U}$ ) produced by centrifugal atomisation were selected [20,21]. They were 
subsequently oxidised after the initial particle manufacturing process using a thermal treatment under air at $200-250{ }^{\circ} \mathrm{C}$ during a few hours. The major crystallographic phase inside the obtained coating is $\mathrm{UO}_{2}$ and its thickness is about $1.0 \mu \mathrm{m}$, as demonstrated by the good agreement between high resolution computed tomography and high energy X-ray diffraction (HE-XRD) measurements [22].

With these oxidised U-Mo powders, four nuclear fuel plates were produced. Fissile particles were embedded in either a pure Al A5 matrix (2 plates labelled 8053 and 8054), or in an Al-2wt.\% Si alloy matrix (2 plates labelled 8043 and 8044). This meat was made of around $50 \%$ vol. U-Mo (i.e. $8 \mathrm{~g} / \mathrm{cc} \mathrm{U}$ ). It has been compacted and further enclosed by an AG3NE frame and an AlFeNi cladding [23]; the composition of these $\mathrm{Al}-\mathrm{Mg}$ and $\mathrm{Al}-\mathrm{Fe}-\mathrm{Ni}-\mathrm{Mg}$ alloys) are given in [24,25]. This assembly has been hot-rolled [26]. A post-manufacturing thermal treatment, often referred to as "blister test", has been performed at temperatures below $450{ }^{\circ} \mathrm{C}$ for one hour. In this paper we focus on the study of the fuel plates containing $\mathrm{Si}$ in the matrix.

Prior to in-pile irradiation, the fresh fuel plates' microstructure has been investigated by HE-XRD detailed in [27], EPMA and optical microscopy presented in the following. In Fig. 1, the different elements of the meat can be clearly distinguished: the U-Mo particles, the oxide layer around the particles, as well as the Al-Si matrix. No signs of elemental mixing between the U-Mo particles and the matrix after the fabrication step could be detected. However, the initially $1.0 \mu \mathrm{m}$ thick $\mathrm{UO}_{2}$ layer has grown during plate manufacturing and exhibits a final thickness of $1.5 \pm 0.5 \mu \mathrm{m}$ as estimated by HE-XRD. Nitrogen maps obtained by EPMA and EDX have shown the presence of a cracked $U_{\mathrm{X}}$ layer in the outer part of the oxide coating (see Figs. 1 and 2). HE-XRD measurements have demonstrated that this layer was mainly made of the $\mathrm{U}_{2} \mathrm{~N}_{3+\mathrm{x}}$ crystallographic phase [27]. Even after this detailed characterisation of both U-Mo particles and as-fabricated fuel plates, it remains quite difficult to determine when this nitrogen contamination has occurred. It is believed that this contamination has occurred during the oxidation treatment of U-Mo powder under air, but it is worth mentioning that no $\mathrm{UN}_{\mathrm{x}}$ phase has been found inside U-Mo particles after their oxidation. It is tentatively proposed that nitrogen was present in solution in the oxide coating and has precipitated in a $\mathrm{UN}_{\mathrm{x}}$ phase as a result of thermal treatments that are part of the fuel plate manufacturing process.

At some U-Mo particle/oxide layer interfaces, a Si-rich diffusion layer (SiRDL) has formed. This results from the diffusion of Si from the matrix towards $U$-Mo particles resulting in the formation of $U_{x-}$ $\mathrm{Mo}_{\mathrm{y}} \mathrm{Si}_{\mathrm{z}} \mathrm{Al}_{\mathrm{v}}$ intermetallics made of two main crystallographic phases: a distorted $\mathrm{U}_{3} \mathrm{Si}_{5}$ and $\mathrm{U}(\mathrm{Al}, \mathrm{Si})_{3}$ with a $4.16 \AA$ lattice constant [27]. This has already been observed in prior similar fresh fuels ([8,16,19,28-30]). HE-XRD measurements have quantified this SiRDL's average thickness and the remaining Si concentration inside the matrix in fuel plates [27] and in mini-plates [31] of different compositions, including oxidised particles. It is concluded that in fuel plates with oxidised U-Mo particles the SiRDL thickness is smaller and the amount of Si remaining inside the matrix is higher. A Si $\mathrm{X}$-ray map shows that an important quantity of $\mathrm{Si}$ remains inside the matrix and that SiRDLs are located at the interface between the U-Mo particles and their oxide coatings (see Fig. 1) [31,32].

HE-XRD also confirmed a slight $\gamma$-U destabilisation into $\alpha^{\prime \prime}-U$ and $\mathrm{U}_{2}$ Mo during the plate manufacturing process.

\subsection{Irradiation conditions}

In 2009, the IRIS 4 irradiation campaign started in the OSIRIS material testing reactor [23]. The fuel plate no. 8043, from which the samples presented in this paper were retrieved, has been irradiated until a final $62 \%$ burn-up $\left({ }^{235} \mathrm{U}\right.$ consumption), with a corresponding fission density of $3.4 \times 10^{21} \mathrm{f} / \mathrm{cm}^{3}$ (mean value averaged over the whole fuel plate) [33]. The peak heat flux was $258 \mathrm{~W} / \mathrm{cm}^{2}$ (BOL), while the outer cladding temperature was around $100{ }^{\circ} \mathrm{C}[34]$.

\subsection{Post irradiation experiments (PIE)}

The results of the post irradiation examinations of two fuel plates from the IRIS4 campaign (i.e. with (8044) and without Si
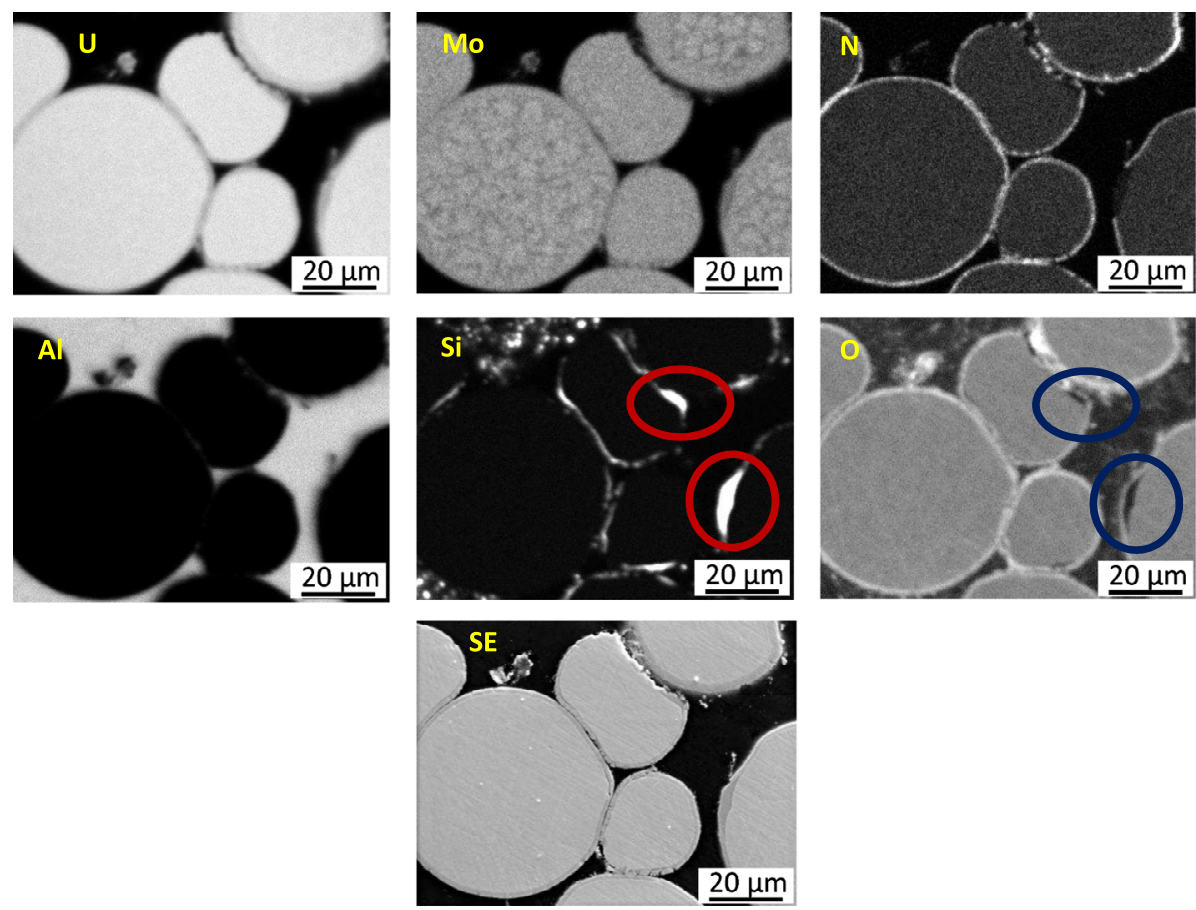

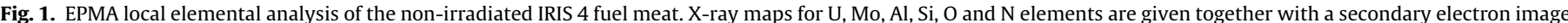

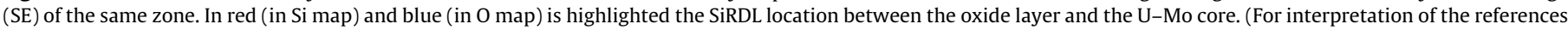
to colour in this figure legend, the reader is referred to the web version of this article.) 

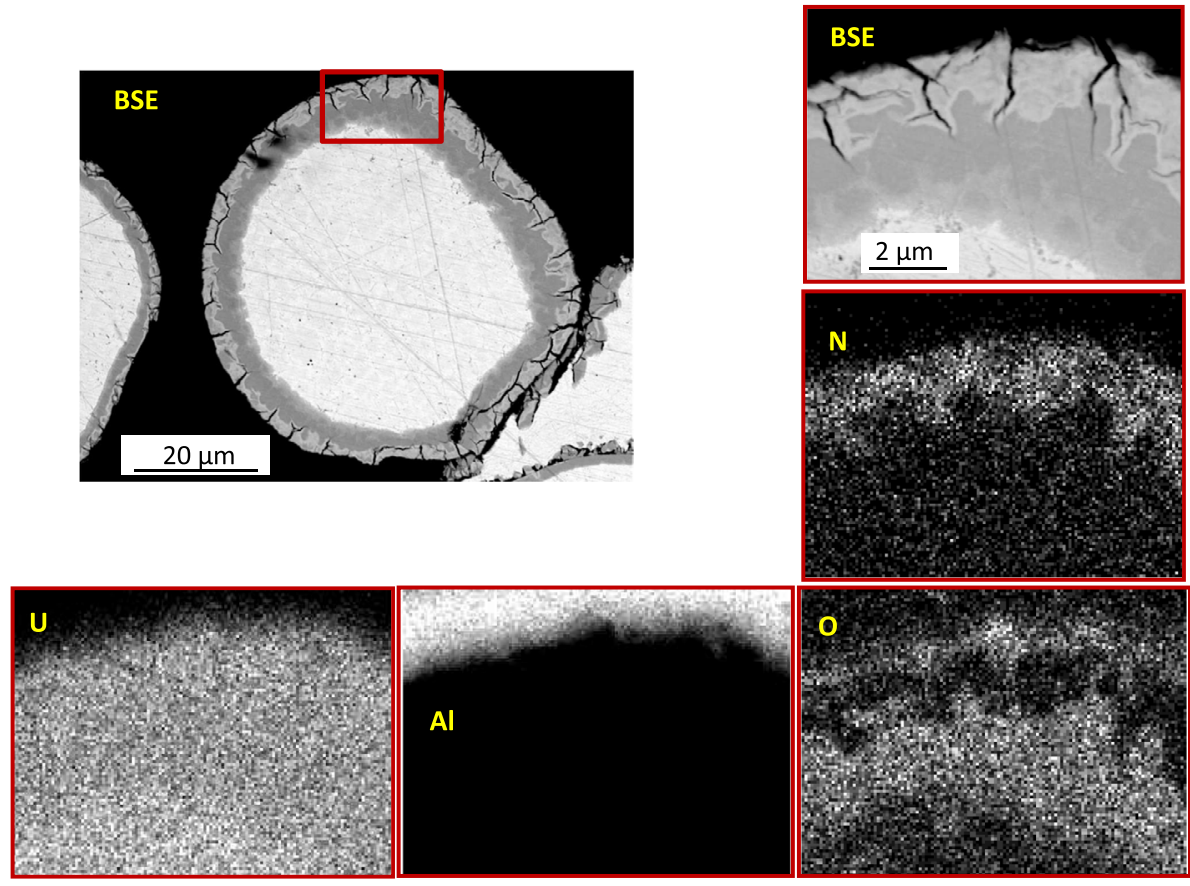

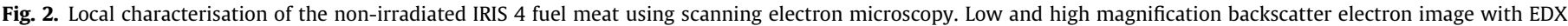
elemental maps. Presence of cracks in the outer part of the coating layer appears to be associated with enrichment in $\mathrm{N}$.

in the matrix (8053)) has already been published elsewhere [33]. In this section, the main results from PIEs performed on plate 8043 (i.e. the plate of interest for this study), are summarised. They are in close agreement with those already presented for plate 8044.

Non-destructive examinations have been performed to measure the fuel plate swelling after in-pile irradiation. The plate thickness was about $1.3 \mathrm{~mm}$ before irradiation. The maximal thickness increase $(0.163 \mathrm{~mm})$ has been found at $345 \mathrm{~mm}$ from the plate bottom. As a comparison, a thickness increase of $0.110 \mathrm{~mm}$ has been measured at the maximum flux plane (MFP) located at $307 \mathrm{~mm}$ with respect to plate bottom. At a second step, destructive examinations including optical microscopy (OM), SEM, X-ray diffraction (XRD) and EPMA measurements were performed to characterise the fuel microstructure. From SEM images taken in the meat region of the fuel (see Fig. 3) one can see the IDL formation around the U-Mo particles. U-Mo core, IDL and matrix surface fractions have been determined by image analysis from EPMA X-ray maps (see Table 1): they are $46 \%, 35 \%$ and $19 \%$ respectively.
Since no $\mathrm{U}_{\mathrm{x}} \mathrm{Mo}_{\mathrm{y}} \mathrm{A}_{\mathrm{z}} \mathrm{l}$ intermetallic crystalline phase has been found using XRD, it is assumed that the IDL is amorphous as expected from experiments performed in similar irradiation conditions and, in particular, temperature [5,6]. Additional X-rays maps obtained with EPMA (see Fig. 4A) show that the IDL exhibits a socalled "duplex" structure, further referred to as an "internal" IDL near the U-Mo/IDL interface and an "external" IDL near the IDL/ $\mathrm{Al}$ interface. The external IDL is oxygen-richer than the internal part of the IDL (see Fig. 4A). Aluminium contents in both parts are very similar, while the Al concentration is slightly higher in the external part (see Table 2).

Si precipitates started to accumulate at the interface between external IDL and matrix. The internal IDL shows no detectable amount of Si. Also, it becomes clear that only a small amount of $\mathrm{Si}$ has been consumed during irradiation. Indeed, there is no clear evidence for precipitate-free zones (PFZ) inside the matrix: Si diffuses towards the U-Mo particles to stabilise them during irradiation (i.e. reduce and slow down the IDL growth). The fact that only a low Si diffusion towards the particles has been observed in the
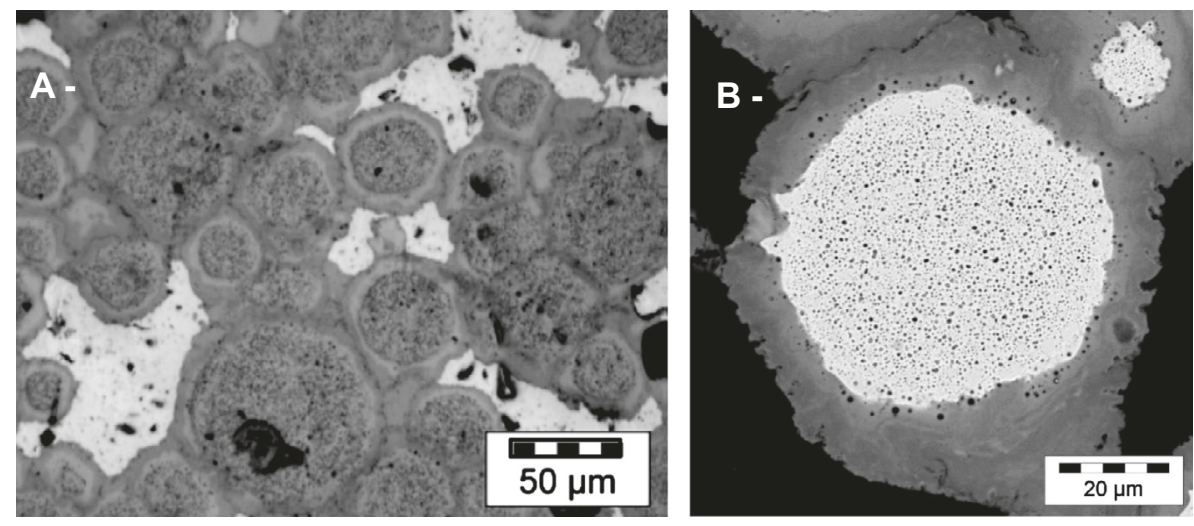

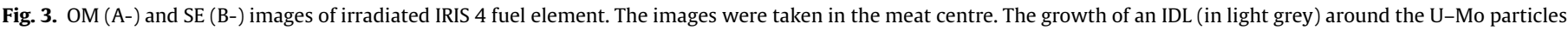
is visible (A-). Inside the U-Mo particles, Xe fission gas bubbles have formed all over the particle as well as at the U-Mo/IDL interfaces (B-) [33]. 
Table 1

Surface fraction of U-Mo, IDL and $\mathrm{Al}$ in the U-Mo meat determined by image analysis of $\mathrm{Al}$ and $\mathrm{U} \mathrm{X}$-ray maps. Large porosities are excluded from this analysis.

\begin{tabular}{lllr}
\hline & \multicolumn{4}{l}{ Surface fraction (\%) } \\
\cline { 2 - 4 } & U-Mo & IDL & Al \\
\hline After in-pile irradiation & 46 & 35 & 19 \\
After thermal treatment at $500{ }^{\circ} \mathrm{C}$ & 48 & 46 & 5 \\
\hline
\end{tabular}

IRIS4 fuel could be attributed to the presence of the $\mathrm{UO}_{2}$ layer around the particles. Concluding, the presence of an $\mathrm{UO}_{2}$ layer around the particles in the IRIS4 experiment has not contributed to the beneficial effect of $\mathrm{Si}$ addition.

The presence of the U-N layer mentioned in Section 2.1 does not result in any notable difference with respect to the general behaviour of the external oxide layer. Experiments aiming at evaluating the interest of nitride coatings are ongoing [36].

Recrystallization inside U-Mo particles (i.e. U-Mo grain subdivision) and the influence of this phenomenon about bubble size inside U-Mo cores has been shown to progress in the 2.0$5.6 \times 10^{21} \mathrm{f} / \mathrm{cm}^{3}$ fission density range [47]. Considering the final fission density in the 8043 plate (see Section 2.2), recrystallization is ongoing, but not complete. It should be reminded that this recrystallization has an influence on the behaviour of fission gases in U-Mo cores: the network of nanometre sized fission gas bubbles present in U-Mo grains before recrystallization would collapse giving rise to larger bubbles (with size close to $1 \mu \mathrm{m}$ ) more homogeneously distributed within the U-Mo core [7] (see Fig. 4A).

In addition to inside the U-Mo particle cores, fission gas bubbles are also present at U-Mo/IDL interfaces (and even in the internal IDL part) and at IDL/IDL interfaces where no matrix remains in between. In these two last locations, they are larger than in the particle cores. If Xe is also found in the external part of the IDL, no significant precipitation can be detected (see Fig. 4A). According to EPMA linescan across the U-Mo particle, the IDL and the matrix (see Fig. 4B), the Xe concentration is found almost constant in the IDL: this suggests that Xe has precipitated in very small bubbles or is present in solution within the IDL. Finally, a peak can also be seen in the matrix close to the IDL which is consistent with the presence of a halo on Xe X-ray maps in this area. This is well known for such heterogeneous nuclear fuels: this is due to fission products implantation in the matrix combined with IDL formation. Xe weight fractions within IDLs seem to be higher around particles located in the meat centre (about $1.8 \mathrm{wt} . \%$ ) than close to the cladding (1.3 wt.\%) (see Table 3 ).

In order to analyse fission gas diffusion inside the fuel (which will be discussed further in this paper), the weight ratio $\mathrm{Xe} / \mathrm{Zr}$ is used (see Table 3). Indeed $\mathrm{Zr}$ can be considered as the best burnup tracer in U-Mo, as this fission product is non-volatile, nondecaying and highly soluble in the U-Mo particle cores (which is not the case for example for Nd at high burn-up). Its measured weight fraction (1.4-1.5 wt.\%) does not significantly evolve with locations within the meat thickness (distance from the cladding).
A-
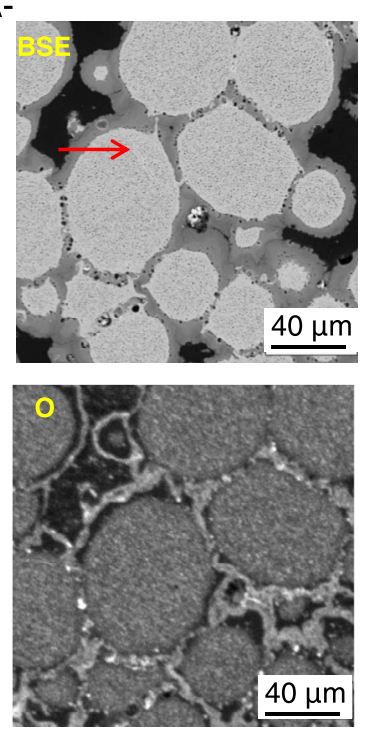
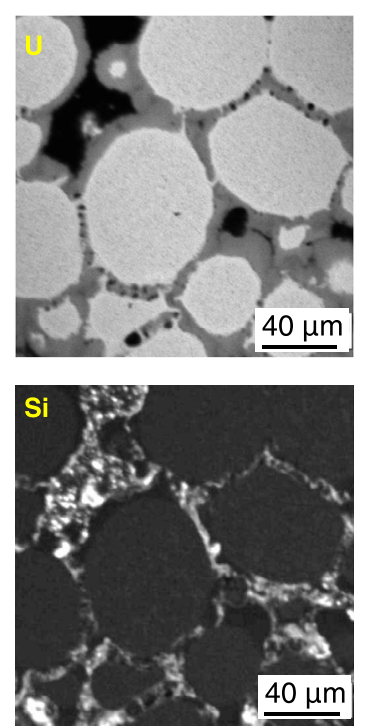
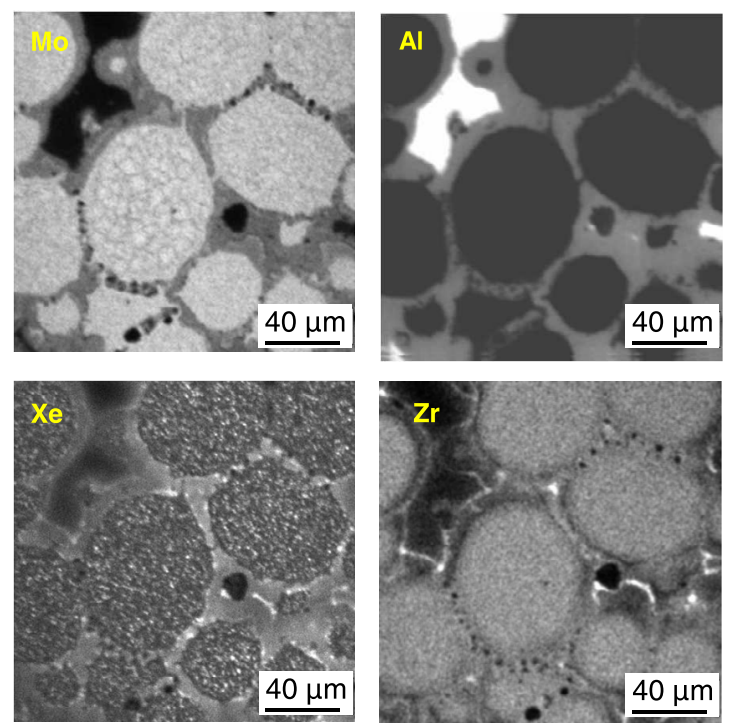

B-
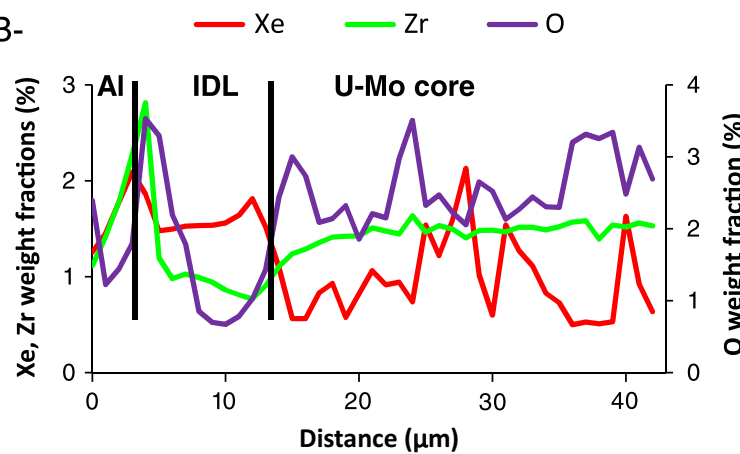

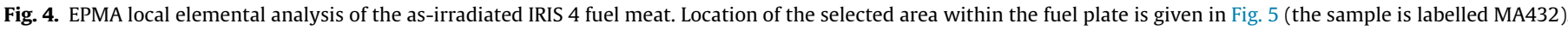

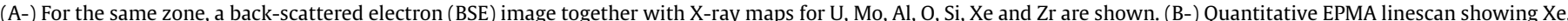

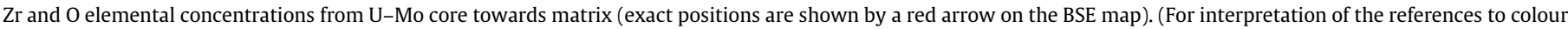
in this figure legend, the reader is referred to the web version of this article.) 
Table 2

IDL elemental composition as determined by quantitative EPMA linescans in in-pile irradiated IRIS 4 fuel plate. Comparison between as-irradiated and post-thermally annealed samples.

\begin{tabular}{|c|c|c|c|c|}
\hline & \multicolumn{2}{|c|}{$\begin{array}{l}(\mathrm{Al}+\mathrm{Si}) /(\mathrm{U}+\mathrm{Mo}) \\
\text { atomic ratio }\end{array}$} & \multicolumn{2}{|c|}{$\begin{array}{l}\text { Si concentration } \\
\text { (at.\%) }\end{array}$} \\
\hline & $\begin{array}{l}\text { Internal } \\
\text { IDL }\end{array}$ & $\begin{array}{l}\text { External } \\
\text { IDL }\end{array}$ & $\begin{array}{l}\text { Internal } \\
\text { IDL }\end{array}$ & $\begin{array}{l}\text { External } \\
\text { IDL }\end{array}$ \\
\hline After in-pile irradiation & $4-5$ & $5-6$ & - & - \\
\hline $\begin{array}{l}\text { After thermal treatment up } \\
\text { to } 500{ }^{\circ} \mathrm{C}\end{array}$ & $3-7$ & $>7$ & $2-4$ & - \\
\hline $\begin{array}{l}\text { After thermal treatment up } \\
\text { to } 670{ }^{\circ} \mathrm{C}\end{array}$ & \multicolumn{2}{|c|}{$\begin{array}{l}3.3-9.6 \text { (No internal/ } \\
\text { external but close to } \\
\text { the cladding/far from } \\
\text { the cladding) }\end{array}$} & \multicolumn{2}{|c|}{$\begin{array}{l}1-5 \text { (relevant only } \\
\text { for IDL around } \\
\text { particles in the } \\
\text { centre of the meat) }\end{array}$} \\
\hline
\end{tabular}

Table 3

Fission product (Xe, $\mathrm{Zr}$ ) weight fractions in IRIS4 fuel plate meat as quantitatively measured by EPMA at three different steps (as irradiated and after thermal treatments up to 500 and $670{ }^{\circ} \mathrm{C}$ )

\begin{tabular}{|c|c|c|c|c|c|c|}
\hline & \multicolumn{6}{|c|}{ Weight fractions (wt.\%) } \\
\hline & \multicolumn{3}{|c|}{ U-Mo core } & \multicolumn{3}{|l|}{ IDL } \\
\hline & $\mathrm{Xe}$ & $\mathrm{Zr}$ & Ratio $\mathrm{Xe} / \mathrm{Zr}$ & $\mathrm{Xe}$ & $\mathrm{Zr}$ & Ratio $\mathrm{Xe} / \mathrm{Zl}$ \\
\hline \multicolumn{7}{|c|}{ After in-pile irradiation } \\
\hline Meat center & 1.1 & 1.5 & 0.7 & 1.8 & 1.4 & 1.3 \\
\hline Close to cladding & 1.2 & 1.5 & 0.8 & 1.5 & 1.1 & 1.3 \\
\hline \multicolumn{7}{|c|}{ After thermal treatment up to $500^{\circ} \mathrm{C}$} \\
\hline Meat center & 0.6 & 1.5 & 0.4 & 1.0 & 1.2 & 0.8 \\
\hline Close to cladding & 0.6 & 1.2 & 0.5 & 0.9 & 1.0 & 0.9 \\
\hline \multicolumn{7}{|c|}{ After thermal treatment up to $670^{\circ} \mathrm{C}$} \\
\hline Meat center & 0.3 & 1.5 & 0.2 & 1.1 & 1.5 & 0.7 \\
\hline Close to cladding & - & - & & 0.2 & 0.8 & 0.2 \\
\hline
\end{tabular}

Average values measured in IDLs and U-Mo cores are also extremely close (except for IDLs located in the vicinity of the cladding). Within IDLs $\mathrm{Zr}$ concentration is not homogeneous: It is lower in the inner part, i.e. close to U-Mo particles and higher closer to the matrix).

The $\mathrm{Xe} / \mathrm{Zr}$ weight ratio was about 0.7 inside the particles and had an average value around 1.3 in the IDL. In fact, in the IDL, this ratio was higher in the internal part (1.6) than in the external part $(0.9)$ as it can be seen in Fig. 4B. This average $\mathrm{Xe} / \mathrm{Zr}$ weight ratio found in the IDL (1.3) corresponds to the theoretical ratio at MFP. This means that, in spite of the relative migrations of $\mathrm{Xe}$ and $\mathrm{Zr}$ within the IDL, Xe did not precipitate into large bubbles. In the particules, on the contrary, the low $\mathrm{Xe} / \mathrm{Zr}$ ratio, when compared to the theoretical yield, is the sign of Xe precipitation and of the release of the gases from the bubbles cut by the polishing process and visible on the BSE image in Fig. 4A. These values are in good agreement with those measured in the IDL inside U-Mo/Al-Si fuel plates irradiated in close temperature conditions but with a higher surface power and up to a higher burn-up [17].

\section{Experimental methods}

\subsection{Sample preparation}

Three samples (labelled TMG434, TMD433 and TMD434) were cut from plate 8043 for further thermal treatments (TT). Their final size was $8 \times 8 \mathrm{~mm}^{2}$.

Fig. 5 shows their location within the plate. For convenience, the location of the sample used for illustrating the results of post-irradiation examinations (labelled MA432) is also indicated in this figure. Since the location of samples MA432 on the one hand and TMG434, TMD433 and TMD434 on the other hand is almost symmetrical with respect to the MFP, it is considered that their burn-up is identical in a first approximation.

\subsection{Thermal Treatments (TT) and on-line FG release monitoring}

The so-called "MERARG-2" (French acronym for Fission Gas Release Study Facility by Annealing) device used for this study consists of a high frequency $(50 \mathrm{kHz})$ induction furnace, located in a hot cell at the LECA-STAR facility (CEA Cadarache centre), coupled with on-line gas release measurements [37,38].

The furnace consists of a metallic crucible (on the centerline of the coil) in which the fuel sample is located. The crucible is made of Pt for tests with air, otherwise made of Mo/W for high temperature tests under inert atmosphere. Between the crucible and the coil, a quartz tube allows to keep the system tight and to collect all the released gases.

A sweeping gas carries the released gases out of the hot cell in order to be analysed in a gloves box located behind the cell. The sweeping gas can be argon or air.

Gases are stored in several collecting tanks, allowing a sequential storage of the experimental gas. Gas analysis is usually performed by:

- On-line gamma spectrometry measurement (in a counting chamber) that allows to monitor ${ }^{85} \mathrm{Kr}$ release or other gas isotopes (such as ${ }^{133} \mathrm{Xe}$ for fresh re-irradiated fuel). The counting chamber and the detector are located in a shielded chamber.

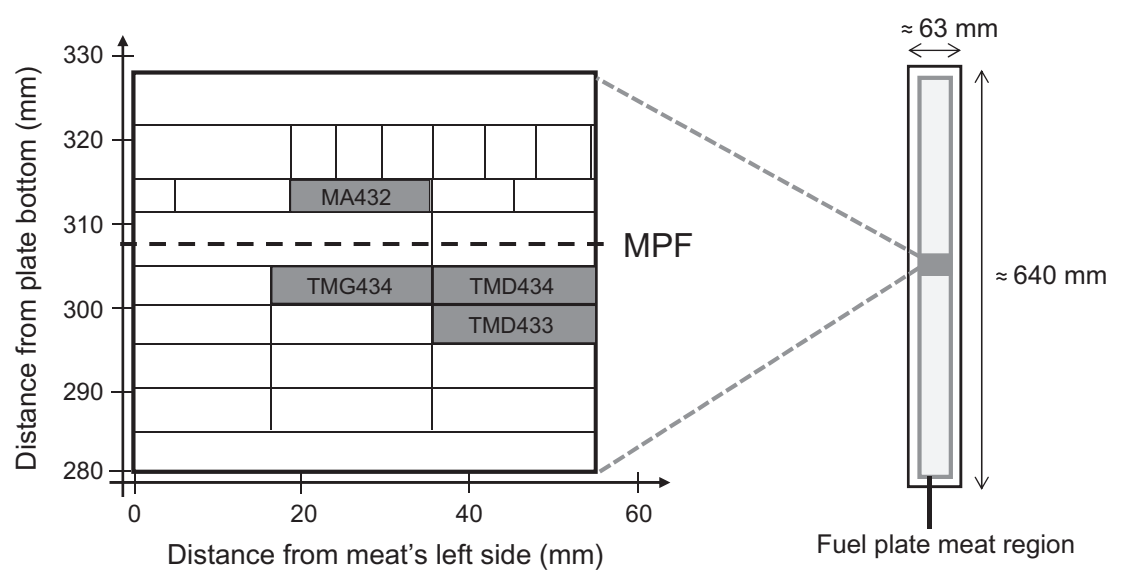

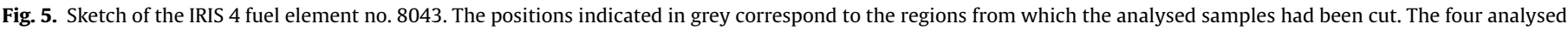
samples were labelled MA432 (as irradiated) TMG434 (heat treated up to $1800{ }^{\circ} \mathrm{C}$ ) TMD433 (heat treated up to $670{ }^{\circ} \mathrm{C}$ ) and TMD434 (heat treated up to $500{ }^{\circ} \mathrm{C}$ ) 


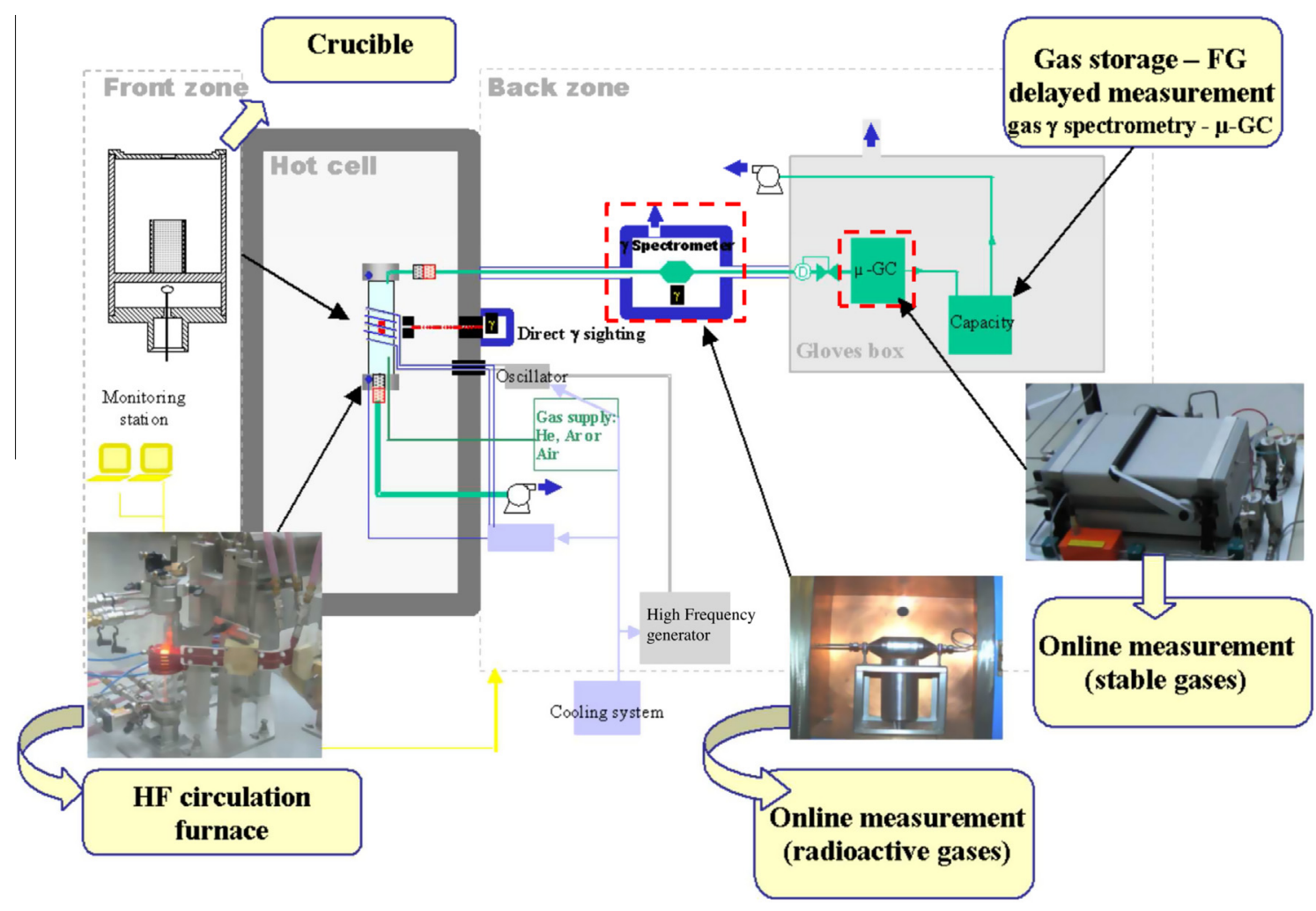

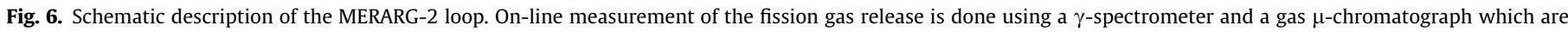

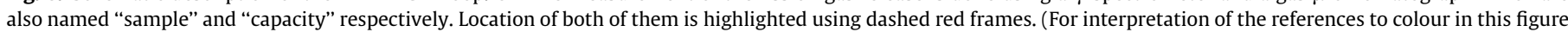
legend, the reader is referred to the web version of this article.)

By taking into account fission gas dilution and flowing time between the furnace and the counting chamber, real fission gas release kinetics at the sample position can be reconstructed from the measured one (i.e. at the $\gamma$ detector position).

- On-line gas chromatography measurement that allows to monitor $\mathrm{He}, \mathrm{H}_{2}$ release or others gases in specific dilution conditions (such as $\mathrm{N}_{2}, \mathrm{Kr}$ and $\mathrm{Xe}$ ).

Instrumentation used to monitor the experiment consists of one high temperature thermocouple, one optical pyrometer, two (inlet and outlet) flow-meters and one pressure transducer.

Fig. 6 shows a schematic overview of the MERARG-2 loop: the locations of both the sample and the gas capacity where ${ }^{85} \mathrm{Kr}$ release is measured are also highlighted. For the three annealing tests performed in this work, a slow temperature increase (i.e. $0.1^{\circ} \mathrm{C} / \mathrm{s}$ ) was chosen to obtain an accurate characterisation of release kinetics. When the target temperature has been reached, the HF furnace has been switched off: holding time at the maximal temperature was very short.

For these experiments, the sweeping gas was argon and a $\mathrm{W}$ crucible was used.

\subsection{Examinations after Thermal Treatments}

After TT, visual inspections have been performed to get a global overview of the annealed samples. It must be mentioned that the first sample (annealed up to $1800^{\circ} \mathrm{C}$ ) was positioned at the sample holder bottom, sticking to the walls. It no longer had its initial fuel plate shape: it had fully melted and optical microscopy suggested that it was homogeneous. As a consequence, this sample has not been analysed further.

The two last samples, which have kept their initial squared shape, have been used for metallography. First, transversal cross sections have been cut from the annealed samples. To increase the area of the region of interest (i.e. the meat), they were not cut perpendicular to the cladding surface. The resulting items were embedded in Wood's alloy. Since very few materials were available, all analyses (OM, EPMA, XRD) had to be performed on the same samples. This has an influence on the quality of measured data especially for XRD (see Section 3.3.2.).

\subsubsection{EPMA}

For EPMA, a shielded electron probe micro-analyser CAMECA SX100R was used. For each analysed zone, X-ray maps (also referred to as "live scans") and/or quantitative line scans using point focus on the one hand and SE or BSE imaging on the other hand have been collected. Incident electron beam characteristics were set at $20 \mathrm{kV}$ and $200 \mathrm{nA}$.

Concerning fission gas quantification (i.e. Xe), it must be reminded that EPMA measurements are only sensitive to elements present in the first micrometre below sample surface and that in case of precipitation, sample preparation has induced a significant release of Xe by cutting (and therefore opening) bubbles: the larger the bubbles, the higher the influence of that release on the EPMA measurements. As a consequence, such measurements underestimate Xe concentration especially when they are located in large bubbles. For a more reliable quantification, it has been suggested to combine for example these characterisations with secondary ion mass spectrometry (SIMS) which do not suffer from this specific limitation [40].

\subsection{2. $X R D$}

A shielded X-ray diffraction system "XRD 3003TT" (from GE inspection Technologies) in horizontal theta-theta geometry has been used. X-rays with two wavelengths (1.5406 and $1.5444 \AA$ ) are produced by a conventional copper tube. The detection system consists of a graphite monochromator and a shielded point detector. 
Table 4

Melting temperatures of non-irradiated materials that could be present in annealed $\mathrm{U}-\mathrm{Mo} / \mathrm{Al}$ nuclear fuel plates. (A) indicates decomposition.

\begin{tabular}{llllllll}
\hline & AlSi 2 wt.\% Si & AlFeNi & AG3Ne & U-7Mo & $\mathrm{UAl}_{2}$ & $\mathrm{UAl}_{3}$ & $\mathrm{UAl}_{4}$ \\
\hline $\begin{array}{c}\text { Melting } \\
\text { temperature }\left({ }^{\circ} \mathrm{C}\right)\end{array}$ & $<700$ & $<700$ & $<700$ & 1145 & 1590 & $1350^{\mathrm{A}}$ & $731^{\mathrm{A}}$ \\
\hline
\end{tabular}

\section{Results}

\subsection{Gas release during annealing tests}

\subsection{1. $\mathrm{Kr}$}

The first heating test has been performed up to very high temperature i.e. $1800^{\circ} \mathrm{C}$ to determine the main temperature regions where fission gas release happens. At $1800^{\circ} \mathrm{C}$, it can reasonably be assumed that only a negligible part of FG remains in the U-Mo samples since this temperature is higher than the $\mathrm{Al}$ (matrix and cladding) and U-7Mo melting temperatures (see Table 4). Fig. 7A shows the release kinetics of ${ }^{85} \mathrm{Kr}$ in this first TT
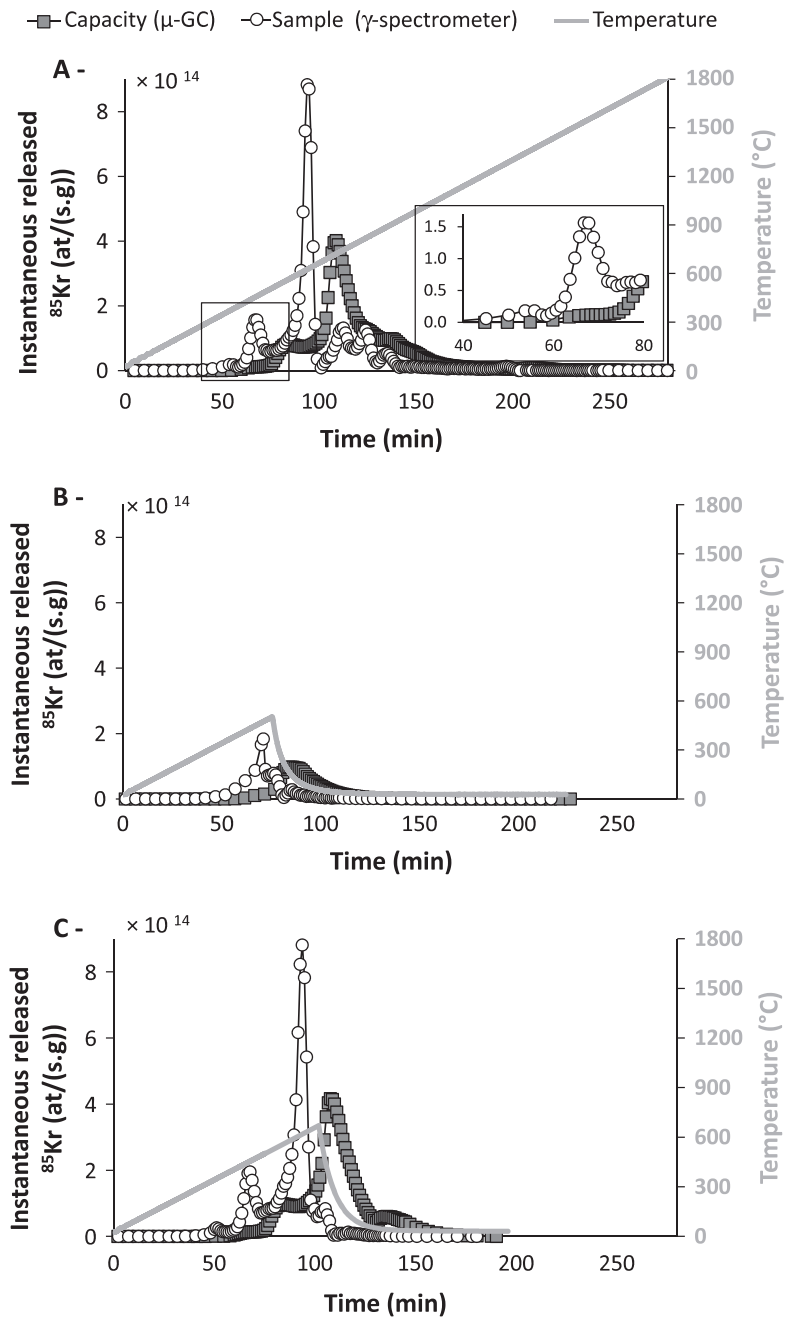

Fig. 7. Measured ${ }^{85} \mathrm{Kr}$ output during the three different thermal treatments performed in the MERARG-2 loop (see Fig. 6 for a schematic view) using similar irradiated IRIS4 nuclear fuel samples. These TTs were performed up to $1800^{\circ} \mathrm{C}(\mathrm{A}-)$ $500{ }^{\circ} \mathrm{C}(\mathrm{B}-)$ and $670{ }^{\circ} \mathrm{C}(\mathrm{C}-)$ respectively without any holding time. The inset in (A-) shows a zoom in the capacity curve (in the [40;80 min] time range) to evidence the presence of two peaks: the associated temperatures are 400 and $500{ }^{\circ} \mathrm{C}$ respectively. performed on sample TMG434. Below $750{ }^{\circ} \mathrm{C}$, release peaks are shown at three temperatures: a broad peak below $400{ }^{\circ} \mathrm{C}$, a second more intense peak at about $500{ }^{\circ} \mathrm{C}$ and a last very intense peak at $670^{\circ} \mathrm{C}$.

Table 2 sums-up these data. The most intense two peaks were chosen as maximal temperatures for the two last TT. As a consequence, samples TMD434 and TMD433 were heat treated up to 500 and $670{ }^{\circ} \mathrm{C}$ respectively. Associated ${ }^{85} \mathrm{Kr}$ release curves are given in Fig. $7 \mathrm{~B}$ and $\mathrm{C}$. Note that reproducibility of these experiments can be seen in the instantaneous ${ }^{85} \mathrm{Kr}$ output values measured in the 2 last TTs which are found in excellent agreement with those obtained in the first one. Indeed ${ }^{85} \mathrm{Kr}$ integral release was 1.5 and $1.5 \times 10^{15} \mathrm{at} / \mathrm{g}^{1}$ for TT up to $500{ }^{\circ} \mathrm{C}$ (TT1 and TT2 respectively) whereas it was 7.8 and $8.5 \times 10^{15} \mathrm{at} / \mathrm{g}$ for TT up to $670{ }^{\circ} \mathrm{C}$ (TT1 and TT3 respectively).

Finally the released ${ }^{85} \mathrm{Kr}$ fraction during sample cooling down to room temperature must be mentioned: it yields $26 \pm 3 \%$ and $6 \pm 2 \%$ of the total released ${ }^{85} \mathrm{Kr}$ quantity for the TT up to 500 and $670{ }^{\circ} \mathrm{C}$ respectively.

\subsection{2. $\mathrm{Xe}, \mathrm{He}$ and $\mathrm{H}_{2}$}

As mentioned previously (see Section 3.2), the release of Xe, He and $\mathrm{H}_{2}$ have also been monitored during the three TTs (using the $\mu-G C)$.

For Xe and He, the release curves appear to be identical to that measured for $\mathrm{Kr}$ if errors associated with measurement statistics are taken into account. Indeed, they exhibit the same shape, the two main peaks being found at the same temperature (500 and $670{ }^{\circ} \mathrm{C}$ respectively). This indicates that the location of Xe and He within the fuel is the same as that of $\mathrm{Kr}$. The absolute released quantities of $\mathrm{Xe}, \mathrm{Kr}$, and $\mathrm{He}$ are however different: the release of about 10 times more $\mathrm{Xe}$ than $\mathrm{Kr}$ and about 15 times more $\mathrm{Kr}$ than He has been measured. Calculations performed for IRIS1 fuel plates (irradiated in the same reactor under close conditions) have shown that the ratio between created $\mathrm{Xe}$ and $\mathrm{Kr}$ was 8.6 which is in close agreement with our measurements.

Concerning $\mathrm{H}_{2}$ and low temperatures (below $700{ }^{\circ} \mathrm{C}$ ), the release curve appears also to be identical to that obtained for $\mathrm{Kr}$. For higher temperatures, an increase of the instantaneous release of $\mathrm{H}_{2}$ is measured, three peaks being found at about 1200,1350 and $1600{ }^{\circ} \mathrm{C}$. These peaks are associated with the thermal decomposition of Aluminium hydroxides (e.g. boehmite) grown during in-pile irradiation on the external part of the cladding.

\subsection{Post-thermal treatment results}

A global OM overview over both samples can be seen in Fig. 8 . As shown in Fig. $8 \mathrm{~A}$ for the $500^{\circ} \mathrm{C}$ sample, one can clearly distinguish between the meat and the cladding region. However, for the $670{ }^{\circ} \mathrm{C}$ sample, this difference between the cladding and the meat region can no longer be clearly identified (see Fig. 8B).

\subsubsection{Thermal treatment up to $500^{\circ} \mathrm{C}$}

4.2.1.1. SE/BSE characterisations. SE images on this sample taken in the meat centre and at the meat/cladding interface are shown in Fig. 9. Inside the U-Mo particles, cracks of around $30 \mu \mathrm{m}$ in length can be seen. Fission gas bubbles located in the core and at the periphery of U-Mo cores do not exhibit huge differences in size. Cracks of approximately the same size as in U-Mo particles are visible in the IDL as well. Considering the IDL thickness, no significant increase can be observed at this step compared to the pre-TT

\footnotetext{
${ }^{1}$ Here the "g" unit indicates that $\mathrm{Kr}$ release has been normalised using the meat weight of each sample.
} 

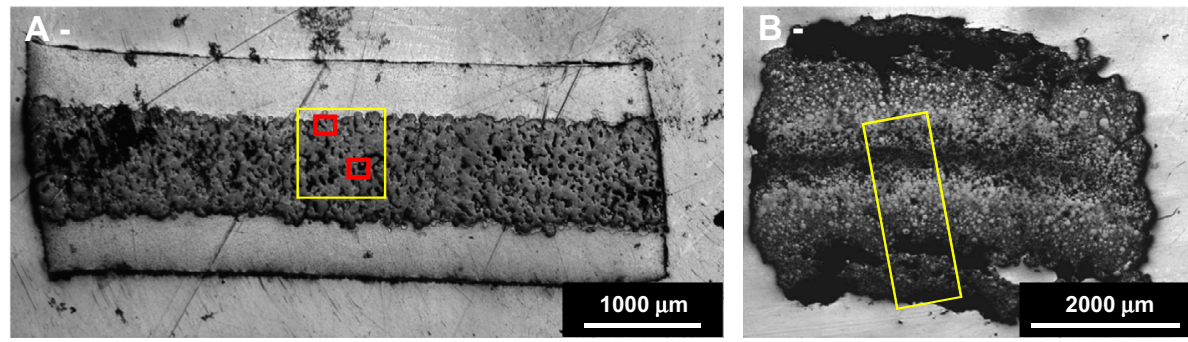

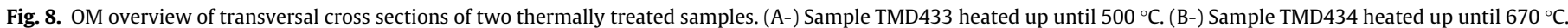
Analysed areas are marked with rectangles.

state. Quantification using X-ray maps is necessary to provide more accurate comparison.

The Al matrix shows no signs of change except the occurrence of cracks in the vicinity of U-Mo particles. Cracks have the same size in both the meat centre and at the cladding interface.

At the IDL/Al interfaces, large interconnected "holes" can be observed (see blue circles in Fig. 9B): in other words matrix and IDLs are not in contact anymore at many locations. These holes can also be observed after TT in similar conditions $\left(475^{\circ} \mathrm{C} 2 \mathrm{~h}\right.$ followed by an additional treatment at $550{ }^{\circ} \mathrm{C}$ for $4 \mathrm{~h}$ ) on nonirradiated U-Mo/Al fuel sample (see Fig. 9C) [41]. This clearly suggests that the development of these holes is not due to fission gases.

4.2.1.2. EPMA. Large $\mathrm{X}$-ray mappings in the meat centre region and at the meat/cladding interface are shown in Fig. 10A for $\mathrm{Al}$ and $\mathrm{Si}$ and in Fig. 11A for Xe and Zr.

One of the most important differences compared to the pre-TT state is the location of $\mathrm{Si}$. Indeed, no $\mathrm{Si}$ remains in the $\mathrm{Al}$ matrix after TT at $500{ }^{\circ} \mathrm{C}$ (see Fig. 10A): it has diffused towards U-Mo particles. It accumulates in the IDL where its concentration may reach 4 at.\%.

O has partly diffused from the outer part of the IDL into the matrix ( $\mathrm{Al}$ ) where it is located close to cracks (see Fig. 10). The IDL still exhibits a duplex structure with an Oxygen-rich external part. However the IDL surface fraction has increased and it seems to be $\mathrm{Al}$ richer (see Tables 1 and 2).

Fission product locations and behaviours have also been characterised by EPMA after this TT up to $500{ }^{\circ} \mathrm{C}$ (see Fig. 11).

$\mathrm{Zr}$ behaviour has not been significantly affected by this TT in the meat centre. In U-Mo particle cores, X-ray maps and linescans confirm that $\mathrm{Zr}$ remains almost homogeneously distributed even if cracks have been observed in these areas. The $\mathrm{Zr}$ average weight fraction in U-Mo particle cores (1.5 wt.\%) has not been modified by this TT (see Table 3 ). In IDLs, $\mathrm{Zr}$ remains faintly present in the internal part but it still accumulates in the external Oxygen rich part. It is difficult to speculate whether Oxygen has hindered a deeper $\mathrm{Zr}$ diffusion in $\mathrm{Al}$. Note that, the lower $\mathrm{Zr}$ average concentration after this TT in IDLs (1.2 wt.\%) could be explained by a $\mathrm{Zr}$ diffusion towards the oxidised part of the matrix. Very close to the meat/ cladding interface, $\mathrm{Zr}$ behaviour in U-Mo particles is different

\section{A- Meat/cladding interface}

B- Meat center region

\section{C- Fresh fuel after annealing}
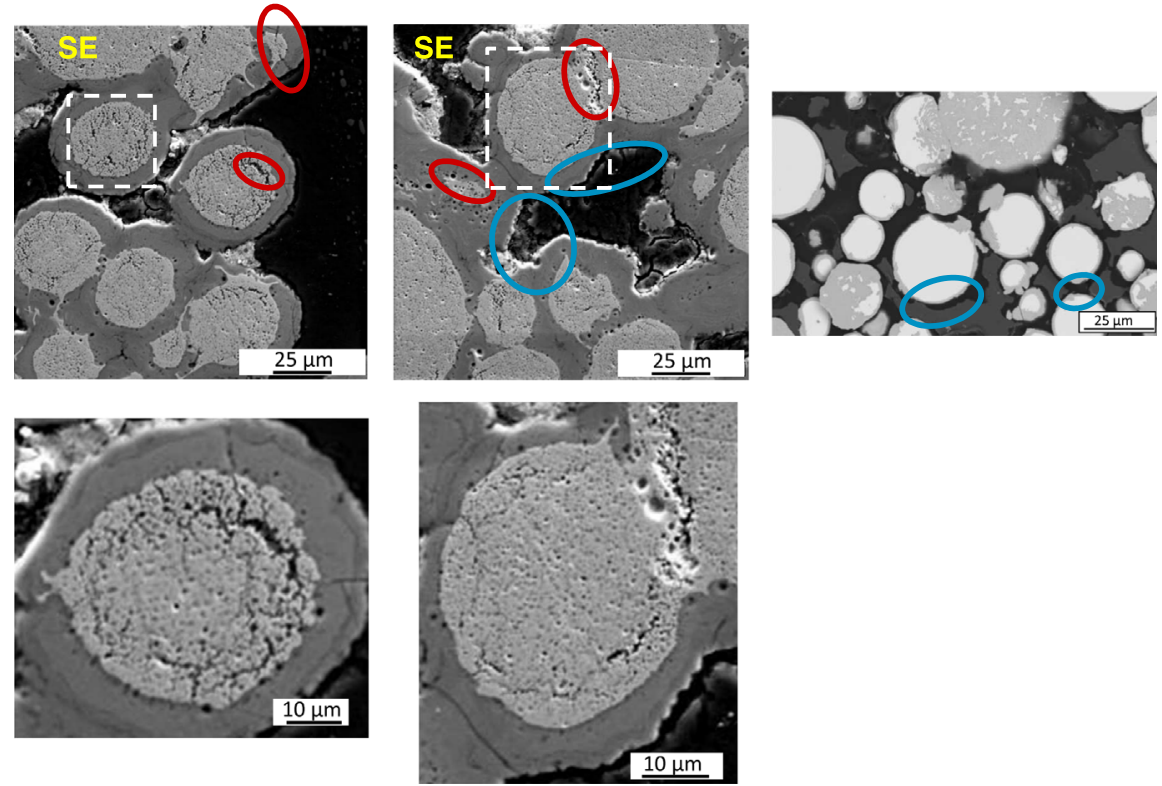

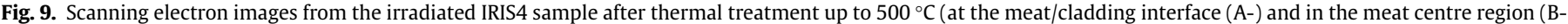

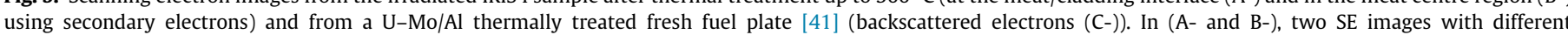

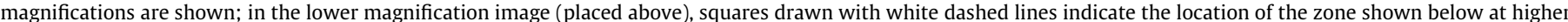

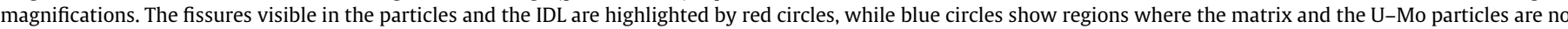
longer in contact. (For interpretation of the references to colour in this figure legend, the reader is referred to the web version of this article.) 
A-
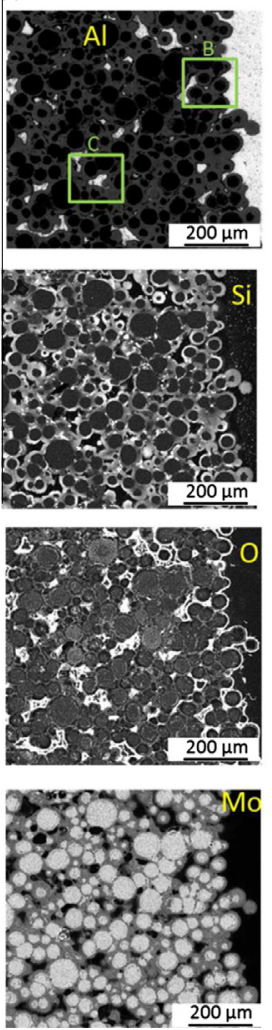

B- Meat/cladding interface
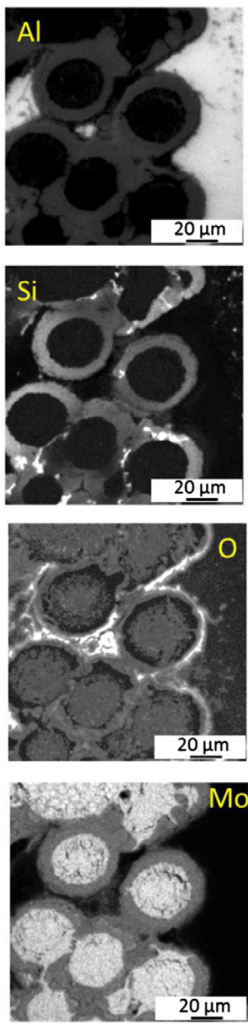

C- Meat center region
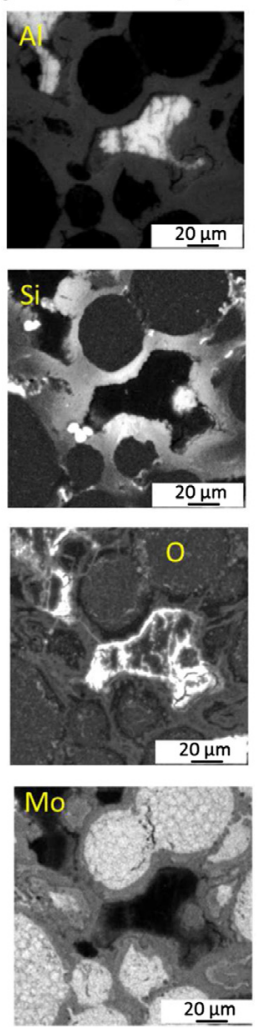
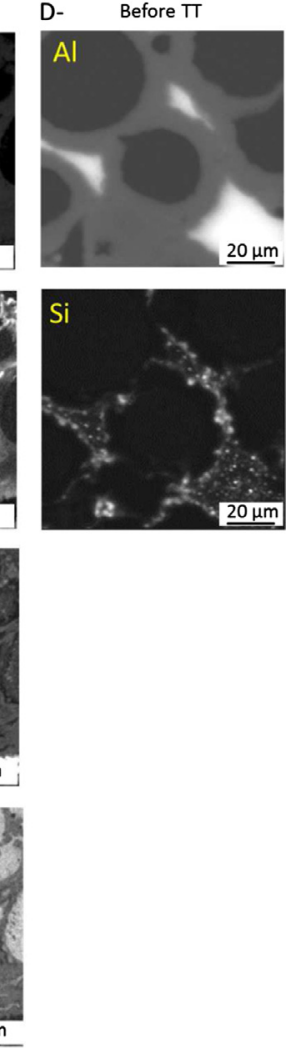

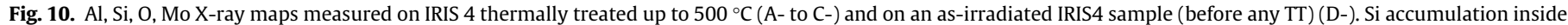

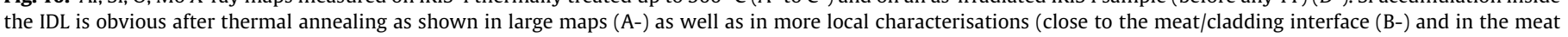
centre area (C-)).
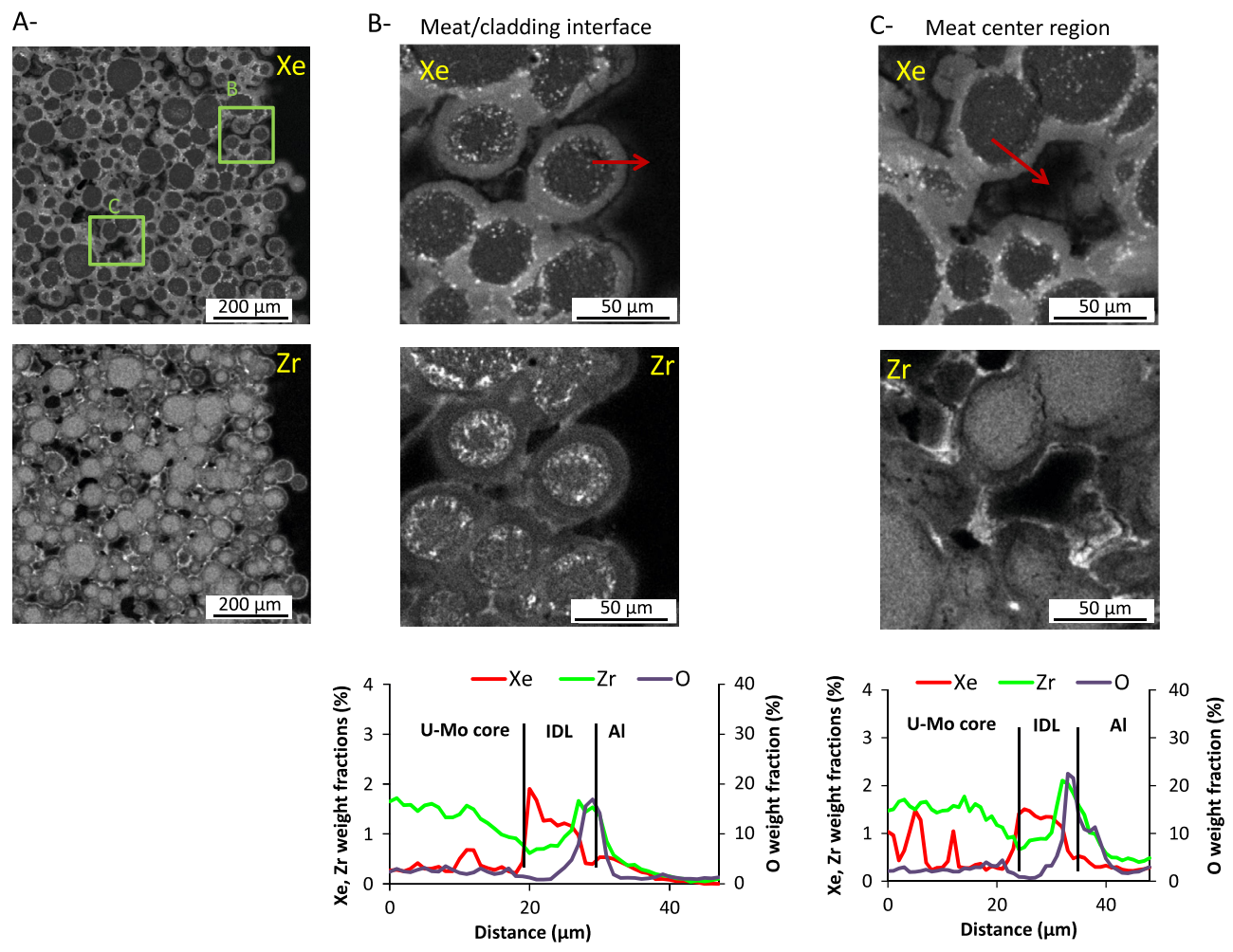

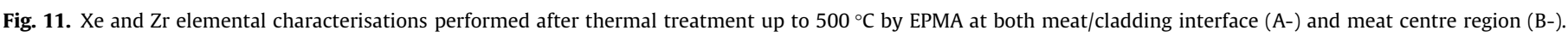

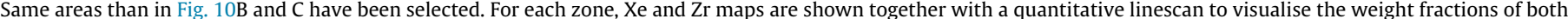

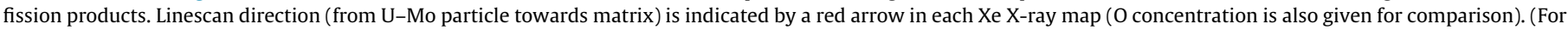
interpretation of the references to colour in this figure legend, the reader is referred to the web version of this article.) 

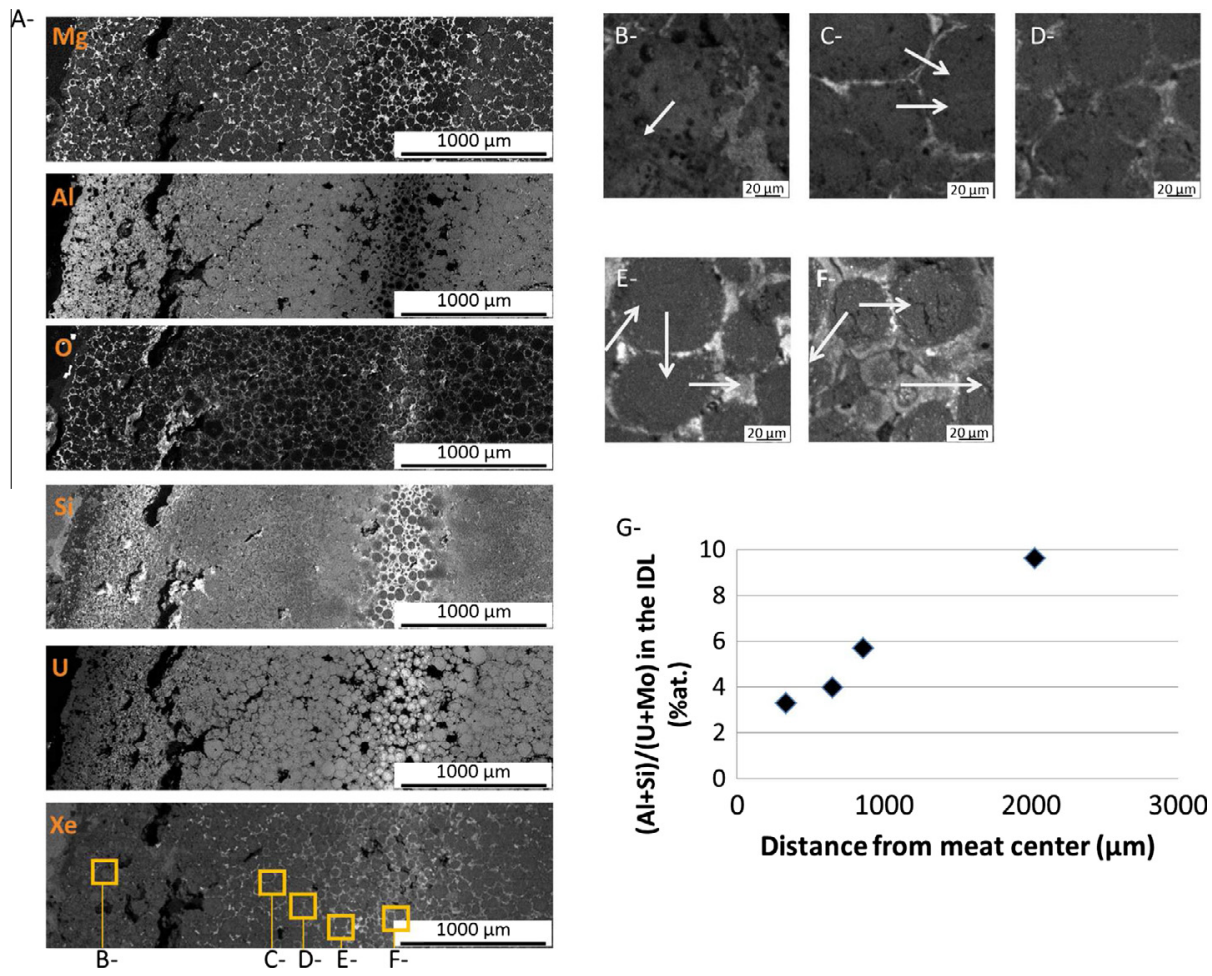

Distance from meat center $(\mu \mathrm{m})$

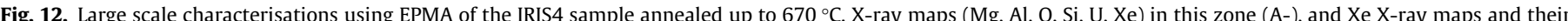

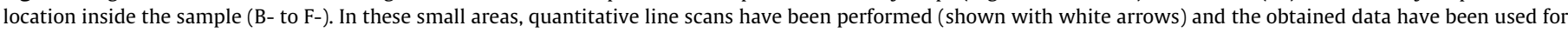
calculation of the $(\mathrm{Si}+\mathrm{Al}) /(\mathrm{U}+\mathrm{Mo})$ ratio evolution with distance from the meat centre $(\mathrm{G}-)$.

(see Fig. 11B). Indeed the U-Mo particle cores centre are depleted in $\mathrm{Zr}$ and this element is present in the outer part of the core in the vicinity of cracks. Close to the cladding interface, $\mathrm{Zr}$ weight fractions are found lower than before the TT.

Low magnification X-ray maps indicate that Xe behaviour has been strongly affected by this TT in the meat centre. Much less Xe bubbles can be seen in U-Mo particle cores and the average Xe weight fraction has strongly decreased (from 1.1 down to 0.6 wt.\%). Xe bubbles are now mainly seen in IDLs close to the U-Mo particle cores.

Closer to the meat/cladding interface, Xe has diffused out of the $\mathrm{U}-\mathrm{Mo}$ particle core centre (as reported for $\mathrm{Zr}$ ); indeed only very few Xe can be seen in these zones. If Xe bubbles can be seen in the outer part of particle cores (in the vicinity of the above mentioned cracks), it is also very likely that some Xe was also trapped in large porosities present in these particles. Close to the meat/ cladding interface, measured Xe weight fractions in particle cores and IDLs are 0.6 and $0.9 \mathrm{wt} . \%$ respectively. Inside the IDL, three different parts can be distinguished. Close to U-Mo/IDL interface (i.e. in the internal part of the IDL), numerous Xe bubbles can be seen. Then, a plateau in Xe concentration (about $1.3 \mathrm{wt} . \%$ ) is observed in the IDL probably associated with the presence of smaller Xe bubbles. In this location, the TT does not seem to have significantly modified Xe concentration. Finally closer to the IDL/matrix interface, a decrease in the Xe concentration is found. If some Xe remains in the matrix close to the IDL (up to $0.5 \mathrm{wt}$.\%), no Xe accumulation can be measured in this area after TT at $500^{\circ} \mathrm{C}$ contrary to what has been measured in the as-irradiated case (spots with Xe weight fraction higher than 0.5 wt.\% could be found in the matrix before TT (see Fig. 4B)).

Whatever the location in the meat (in the IDL or in U-Mo cores, in the meat center or close to the cladding), the $\mathrm{Xe} / \mathrm{Zr}$ weight ratio decreases as compared to the as-irradiated state; this decrease is stronger for U-Mo cores than for IDLs. EPMA measurements may lead to an underestimation of the Xe content in U-Mo particles but not in IDLs. Indeed, the large Xe bubbles present in U-Mo particle cores may have been cut during preparation but a high amount of such large Xe bubbles are not visible in IDLs. Based on these observations, it can be proposed that Xe has diffused out of U-Mo core centres towards IDLs but also from IDLs towards the IDL/matrix interface.

4.2.1.3. XRD. The main contributions to the XRD pattern in the $500{ }^{\circ} \mathrm{C}$ sample are coming from $\alpha-\mathrm{U}, \gamma-\mathrm{U}-\mathrm{Mo}, \mathrm{Al}$ and $\mathrm{UAl}_{3}$. The occurrence of $\alpha-U$ is attributed to the destabilisation of the $\gamma$-U-Mo metastable phase, which is expected at $500^{\circ} \mathrm{C}$ [42]. Accordingly, the $\gamma-\mathrm{U}-\mathrm{Mo}$ lattice parameter has decreased to $3.427 \AA$ from the former pre-TT value of $3.440 \AA$. This variation could be caused by the $\gamma$-U-Mo destabilisation as observed on fresh samples (see for example [27] and references therein). The precipitation of fission products originally dissolved in the $\gamma$-U-Mo lattice could also have induced this lattice contraction.

The presence of the (111) $\mathrm{UAl}_{3} \mathrm{Bragg}$ line suggests that the IDL recrystallization has started. However, it should be mentioned that the (100) and (110) $\mathrm{UAl}_{3}$ Bragg lines are missing.

\subsubsection{Thermal treatment up to $670{ }^{\circ} \mathrm{C}$}

To complement a first OM overview of the sample transverse cross section (Fig. 8B), SE and X-ray maps are presented at two scales (overview in Fig. 12A and zooms in Fig. 13).

4.2.2.1. SEM characterisations. As mentioned before, a clear U-Mo particle shape can only be detected in the very centre of the sample (Fig. 8B). For the rest of the sample (i.e. closer to the cladding), a strong interaction between the $\mathrm{Al}$ and the $\mathrm{U}-\mathrm{Mo}$ particles occurred: no pure Al zone associated with the matrix or the cladding can be observed anymore making the location of individual U-Mo particles difficult. Moreover, some particles from the meat 

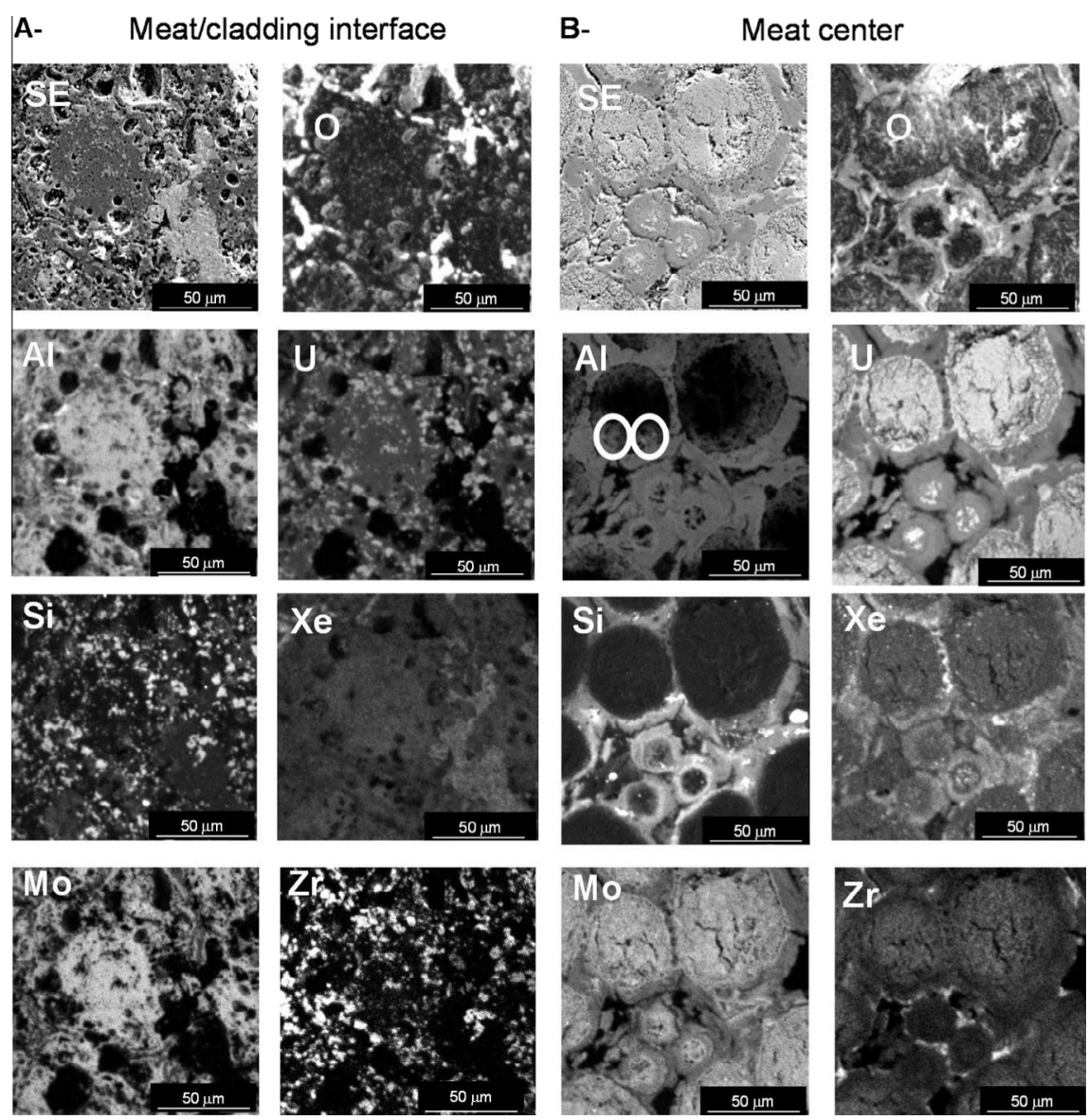

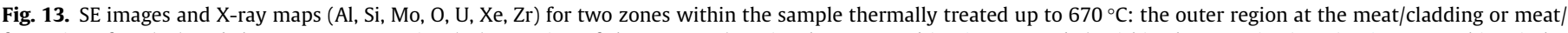

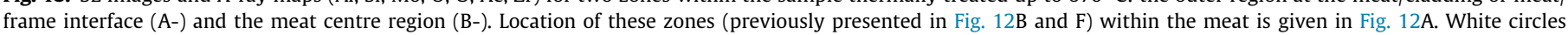
represent areas where $\mathrm{Al}$ diffusion into the $\mathrm{U}-\mathrm{Mo}$ particles has occurred.

centre have moved towards the cladding which could be a consequence of both matrix and cladding melting (see Table 4).

Fissures can as well be detected in the meat centre, just as in the $500{ }^{\circ} \mathrm{C}$ sample. Although the final temperature was higher, the fissures are not larger than in the U-Mo particles in comparable regions of the sample thermally annealed up to $500{ }^{\circ} \mathrm{C}$. Huge porosities of up to several tens of micrometres in diameter have appeared closer to the initial cladding location (i.e. in the full $\mathrm{U}-\mathrm{Mo} / \mathrm{Al}$ interaction zone). Fission gases were probably present in these porosities before their release (see Section 4.1.1) indicating that fission gas behaviour has strongly been influenced by temperature and U-Mo/Al interaction. The outer part of the sample, which corresponds to the initial cladding location, has become very brittle and millimetre sized cracks along the cladding/meat interface have appeared. These cracks may have also been caused by sample preparation (see Fig. $8 \mathrm{~B}$ ).

4.2.2.2. EPMA. Large scale X-ray maps for $\mathrm{Mg}$ (see Fig. 12) and Fe (not reported here) show that these elements initially present in the cladding and in the frame have extensively diffused towards the meat centre. In the meat centre, Mg is located in IDLs (never in U-Mo cores), and in the outer part of the sample this element can be found around interacted particles (not in their cores). As a conclusion, the location of $\mathrm{Mg}$ is very close to that of $\mathrm{O}$ elements after TT at $670{ }^{\circ} \mathrm{C}$ (see Fig. 12A). Concerning Fe, X-ray maps suggest that this element has less rapidly diffused towards the meat centre. As a result of the lower amount of Fe in this area, the analysis of its location in both IDLs and U-Mo particle cores is very difficult. The behaviour of $\mathrm{Al}$ initially in the cladding or in the frame is more complex: it is assumed that it also diffused towards the meat centre, but on its way Al may have interacted with U-Mo particles. This hypothesis is in agreement with the already mentioned higher rate of $\mathrm{U}-\mathrm{Mo} / \mathrm{Al}$ interaction at the meat/cladding (or frame) interface than in the meat centre. Note that Al self-diffusion has been found to be much quicker at temperatures close to Al melting point than Fe diffusion in $\mathrm{Al}$ [44] (no data have been found regarding $\mathrm{Mg}$ diffusion into $\mathrm{Al}$ ). To fully validate this interpretation, Ni location should be characterised in this sample: its diffusion coefficient in $\mathrm{Al}$ is supposed to be much higher than Fe [44] and both elements are present in the cladding material with comparable weight fractions [25].

Close to the meat/cladding interface, a total interdiffusion between the $\mathrm{U}$-Mo particles, the $\mathrm{Al}$ matrix and the cladding has occurred. Al has diffused into all U-Mo particles (see Figs. 12A and $13 \mathrm{~A}$ ) while the matrix significantly lacks this element. The $\mathrm{Al}$ content is however not fully homogeneous here (see Fig. 13C). In the meat centre region, where a less drastic $\mathrm{U}-\mathrm{Mo} / \mathrm{Al}$ interaction occurred, one can observe the beginning Al diffusion inside the U-Mo particles (see white circles in Fig. 13B). An interesting intermediate case can be observed in the meat area illustrated by Fig. 12E. For the three quantitative data collections performed in this zone by EPMA, the Al weight fraction is found almost constant over the linescans i.e. it is the same in IDLs and U-Mo particles; it equals to about $30 \mathrm{wt} . \%$ here.

The oxygen content is found much higher in this sample than the one annealed up to $500{ }^{\circ} \mathrm{C}$ whatever the location within the meat (see Fig. 14A and B). Close to the initial cladding location, this concentration may reach $20 \mathrm{wt} . \%$ but appears strongly 

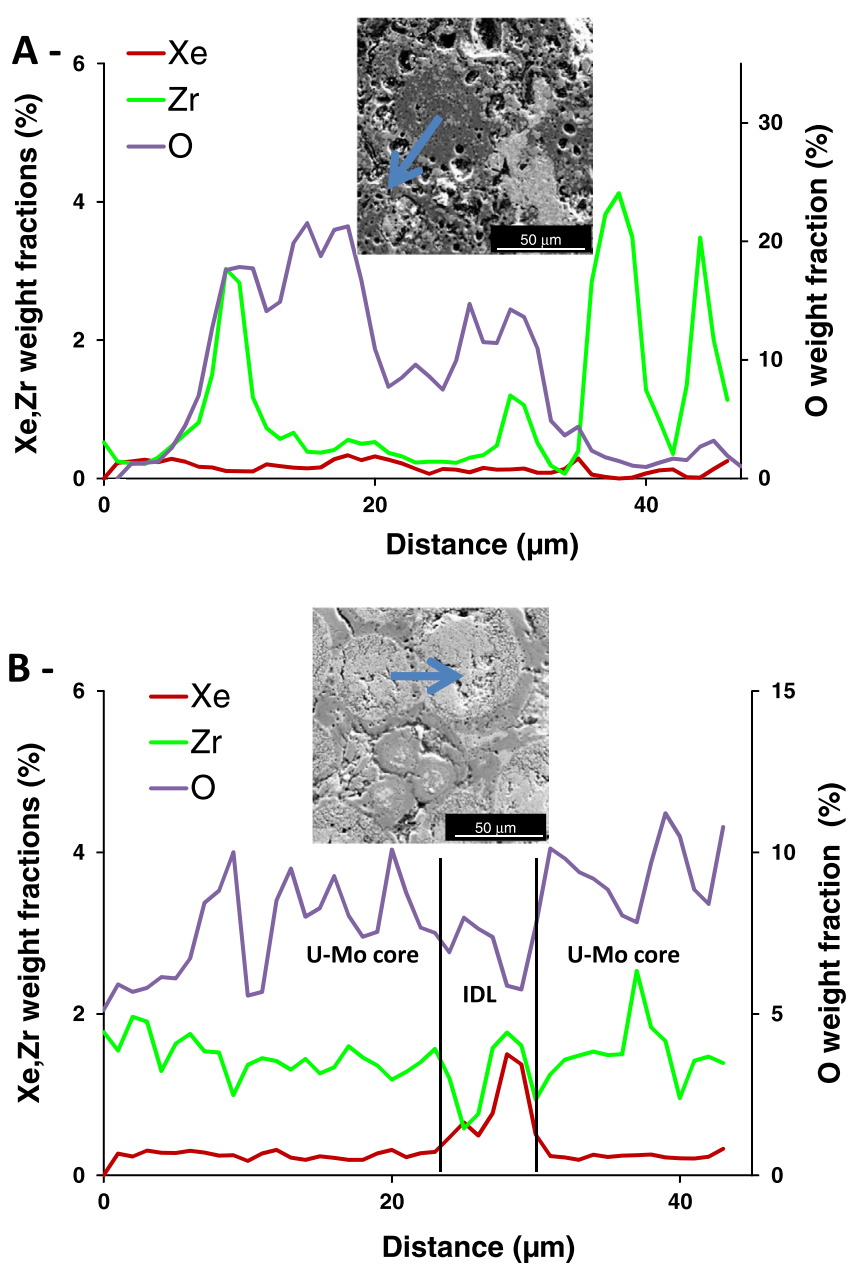

Fig. 14. EPMA linescans showing the $\mathrm{Xe}, \mathrm{Zr}$ and $\mathrm{O}$ weight fractions at (A-) the meat/ cladding or meat/frame interface and (B-) the meat centre region of the sample thermally annealed up to $670{ }^{\circ} \mathrm{C}$. Linescan directions are highlighted by blue arrows on the SE image added as an inset. (For interpretation of the references to colour in this figure legend, the reader is referred to the web version of this article.)

heterogeneous. Areas between U-Mo particles are generally enriched with this element which is less obvious close to the cladding as a consequence of the U-Mo/Al interaction.

At the cladding regions, it also became obvious that new compounds have formed: When comparing $\mathrm{Al}, \mathrm{Si}, \mathrm{U}$ and Mo locations on X-ray maps (Fig. 13A), it is obvious that regions rich in $U$ are lacking $\mathrm{Al}$ and Mo. Accordingly, Si can be found at the same spots as $U$. Therefore it is concluded that $\mathrm{Al}_{\mathrm{x}} \mathrm{Mo}_{\mathrm{y}}$ and $\mathrm{U}_{\mathrm{x}} \mathrm{Si}_{\mathrm{y}}$ rich compounds have been created. Calculating the $(\mathrm{Si}+\mathrm{Al}) /(\mathrm{U}+\mathrm{Mo})$ atomic ratios from the meat centre towards the cladding, one obtained a value of 3.3 for the meat centre increasing to 9.6 at the sample outer limit (see Fig. 12G).

These microstructural modifications have strongly influenced fission product behaviour. In the meat centre, $\mathrm{Zr}$ behaviour remains almost identical to the one observed after TT at $500{ }^{\circ} \mathrm{C}$ in this area: the measured $\mathrm{Zr}$ weight fraction in $\mathrm{U}-$ Mo particles and in the IDL is identical (i.e. 1.5 wt.\%). In U-Mo particles this $\mathrm{Zr}$ weight fraction is not as homogeneous as observed for the as-irradiated case or even after TT at $500^{\circ} \mathrm{C}$. Very close to the initial cladding location, $\mathrm{Zr}$ behaviour is from far different: it has dramatically precipitated in the U-Mo/Al interacted zone (see Figs. 13A and 14A). The measured $\mathrm{Zr}$ average weight fraction in this area is lower than usually observed ( $0.8 \mathrm{wt} . \%)$ but this value could have been underestimated as a result of the high heterogeneity of the $\mathrm{Zr}$ distribution.
As shown on Xe X-ray maps (see Fig. 13A and B), this element is only very faintly detected at the cladding interface while a higher amount can be found in the meat centre. Linescans performed in these two areas confirm this observation. Close to the cladding, the Xe average weight fraction is very low $(0.17 \mathrm{wt} . \%)$ but averaged values are constant from one scan to another. The three scans shown in Fig. 12B and $\mathrm{C}$ are considered here, excluding data collected between two former particles i.e. in the over-oxidised zone. This homogeneous Xe distribution close to the initial cladding location suggests that it is mainly present in solution or that it has precipitated into small bubbles. An important part of Xe has therefore been released in this area.

Indeed, successive linescans close to the cladding or frame and in the meat centre (see Fig. 14A and B) show an average Xe weight fraction of $0.3 \%$ and $1.1 \%$ respectively. Moreover, linescans in the meat centre confirm that Xe diffuses more easily towards the IDL than $\mathrm{Zr}$ : the $\mathrm{Xe} / \mathrm{Zr}$ weight ratio evolves from 0.2 inside the particles up to 0.7 in the IDL (see Table 3). Close to the cladding this ratio becomes very low: about $0.3 \mathrm{wt} . \%$.

\section{Discussion}

\subsection{Microstructural evolutions in temperatures}

Very limited data are available concerning microstructure evolutions in MTR fuel during thermal annealing. The most detailed study has been performed on an $\mathrm{UAl}_{\mathrm{x}} / \mathrm{Al}$ fuel plate which had undergone a coolant flow blockage incident [43]. If blister tests on in-pile irradiated $\mathrm{U}_{3} \mathrm{Si}_{2}$ plates have been reported in literature [39], very few associated destructive examinations are provided. Within this framework, microstructural investigations provided in this paper are extremely valuable. They are illustrated and summed-up in Table 6 and Fig. 15. A focus on three specific points is given in the following.

\subsubsection{IDLS}

At $500^{\circ} \mathrm{C}$, the slight increase in IDL thickness seems to have occurred all over the fuel plate meat and will not be further discussed. This section is focused on the interpretation of the heterogeneous rate of $\mathrm{U}-\mathrm{Mo} / \mathrm{Al}$ interaction observed after TT up to $670{ }^{\circ} \mathrm{C}$.

First it is believed that no important thermal gradient did exist across the plate thickness during the thermal treatment. Indeed, the sample thickness is small (about $1.3 \mathrm{~mm}$ ) and the thermal conductivities of $\mathrm{Al}$ and U-Mo are relatively high. Even if the IDL's thermal conductivity is not accurately known yet, and even if irradiation has induced a decrease of thermal conductivity, it is not believed that such a modification will be significant enough to induce a thermal gradient in the plate during heating at $0.1^{\circ} \mathrm{C} / \mathrm{s}$.

The quantity of available $\mathrm{Al}$ throughout the meat thickness is a more reliable explanation for the heterogeneous rate of $\mathrm{U}-\mathrm{Mo} / \mathrm{Al}$ interaction. Three arguments are proposed to back-up this interpretation. Firstly, alloying elements (i.e. $\mathrm{Mg}$ ) inside the cladding/ frame are found around interacted U-Mo particles, suggesting that Al from the cladding has also been mobile during the TT (see Figs. 12 and 13). There is no matrix left between U-Mo particles in the meat centre (see Fig. 13) which may have limited U-Mo/Al interaction in this area. Secondly, an out-of-pile study confirms that the lower the U-Mo fractions in U-Mo/Al samples, the higher the U-Mo/Al interaction rate [45]. In this work, four un-irradiated $\mathrm{U}-\mathrm{Mo} / \mathrm{Al}$ compacts with different U-Mo loadings (from 10 to 50 volume percents) have been thermally annealed up to $700{ }^{\circ} \mathrm{C}$. Subsequent SEM investigations of these annealed samples have revealed full interaction of U-Mo atomised particles with Al matrix for the lowest U-Mo loading and the quantity of IDL has decreased 
Table 5

Measured released fission gas fraction and proposition about their location inside the sample/microstructure.

\begin{tabular}{|c|c|c|c|}
\hline \multirow[t]{2}{*}{ Temperature $\left({ }^{\circ} \mathrm{C}\right)$} & \multicolumn{2}{|l|}{ Fission gas release $(\%)$} & \multirow[t]{2}{*}{ Sample location of fission gas release } \\
\hline & Per temperature interval & Integration & \\
\hline$<400$ & 2.4 & 2.4 & Volumes close to sample surfaces + fissure network inside the fuel (unlikely) \\
\hline $400<T<500$ & 13.8 & 16.2 & $\begin{array}{l}\text { IDL / matrix interfaces: } \\
\text { - in the external part of the IDL } \\
\text { - in large porosities at this interface } \\
\text { - in the } \mathrm{Al} \text { (implanted fission gases) } \\
\text { Possible contribution from U-Mo particle cores }\end{array}$ \\
\hline $500<T<670$ & 57.0 & 73.2 & U-Mo particles closer to the cladding IDL at total interaction zones \\
\hline$T>670$ & 26.8 & 100 & U-Mo core in particles located far from the cladding (until total interaction) \\
\hline
\end{tabular}

Table 6

Summary of post-treatment observations (EPMA, XRD): after in-pile irradiation, after thermal treatment up to $500{ }^{\circ} \mathrm{C}$, and after thermal treatment up to $670{ }^{\circ} \mathrm{C}$.

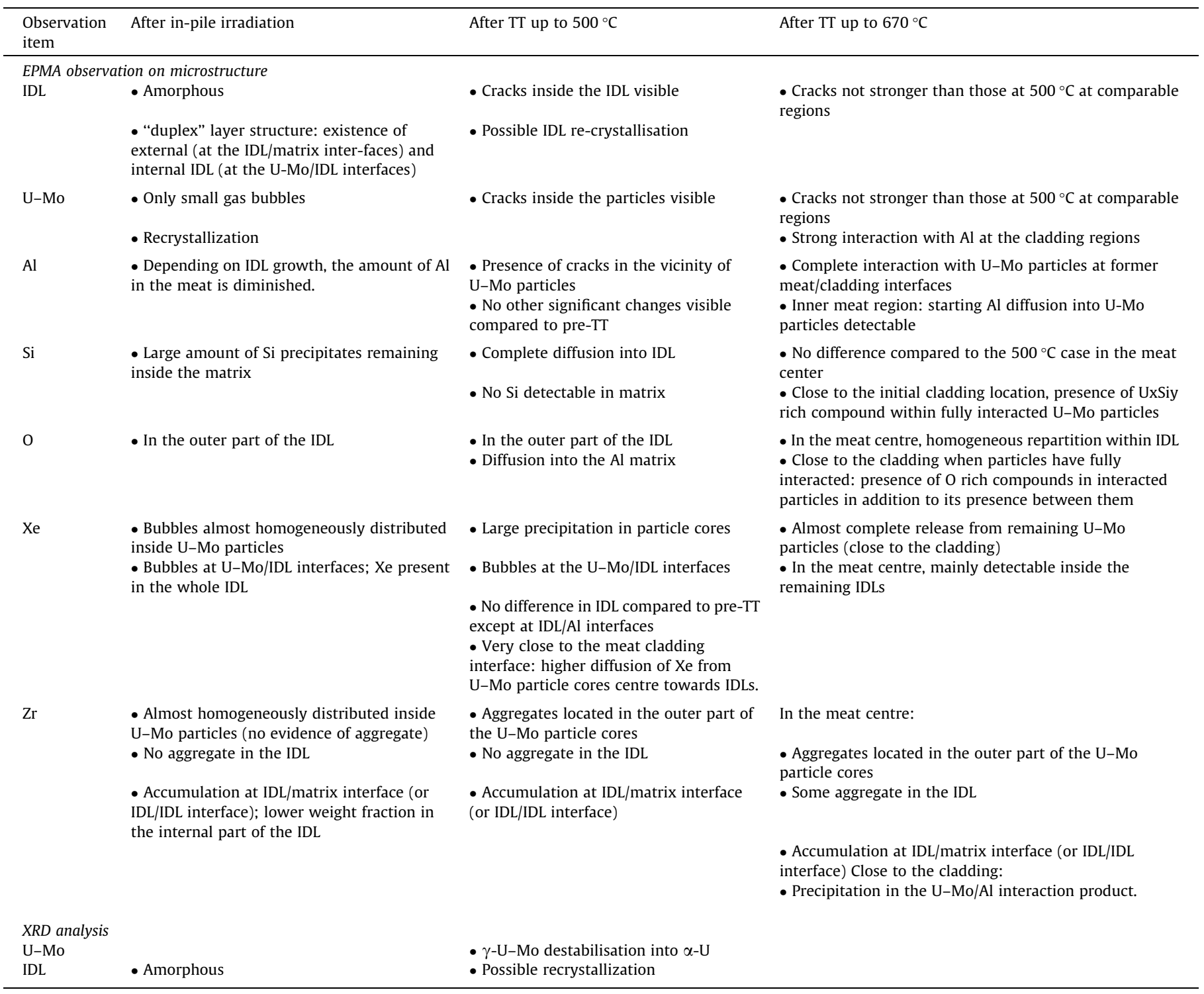

with increasing U-Mo loading. Some differences between both experiments do exist: fresh/irradiated, molybdenum content in U-Mo particles (10 and 7 wt.\%), coating (none versus oxide), matrix composition (pure $\mathrm{Al}$ and $\mathrm{Al}-\mathrm{Si} 2 / \mathrm{AlFeNi}$ ), heating rates (10 and $6^{\circ} \mathrm{C} / \mathrm{min}$ ) and final temperatures $\left(700\right.$ and $670{ }^{\circ} \mathrm{C}$ ). However, similarities between both experiments are extremely striking. In the annealed fuel plate of interest for this study, U-Mo particles close to the cladding exhibit the same behaviour as those from the annealed compact with 10 vol\% U-Mo loading in [45] and U-Mo particle in the meat centre are very close to those obtained after annealing of compacts with 50 vol\% U-Mo loading. Finally, Ryu et al. have used differential scanning calorimeter to further investigate $\mathrm{U}-\mathrm{Mo} / \mathrm{Al}$ interaction. They show that for compacts loaded with $50 \mathrm{vol} \% \mathrm{U}-\mathrm{Mo}$ (i.e. average loading for fuel plate meat) a strong exothermic reaction occurred at $650{ }^{\circ} \mathrm{C}$. This temperature is tentatively associated with the strong fission gas release measured 

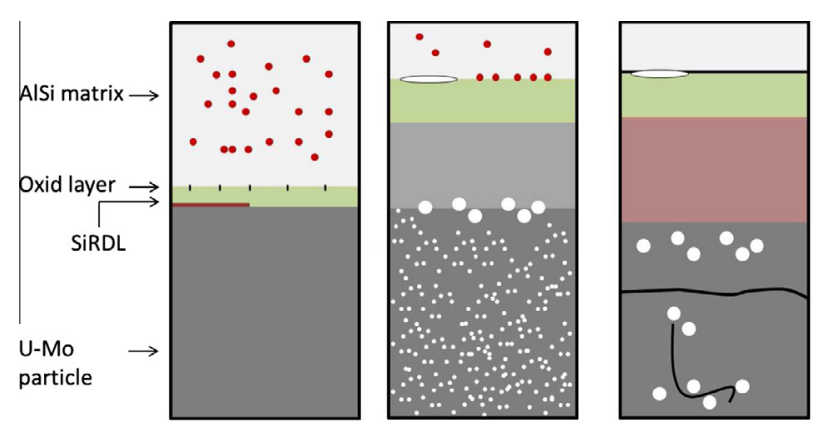

As-manufactured
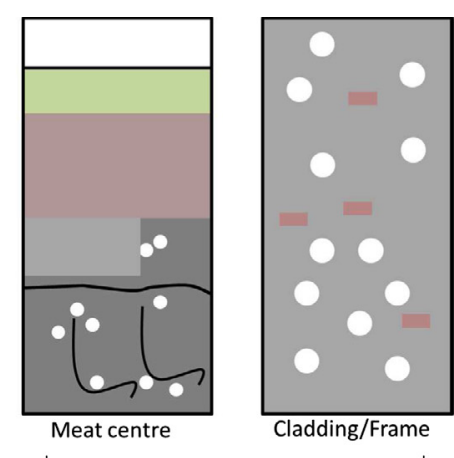

After TT up to $670^{\circ} \mathrm{C}$

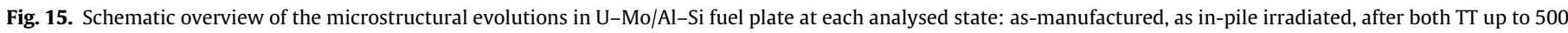
and up to $670^{\circ} \mathrm{C}$.

here at $670{ }^{\circ} \mathrm{C}$ (see Fig. 7A) on in-pile irradiated fuel plate samples.

\subsubsection{Si and oxide effects}

The influence of the two engineering approaches (oxide coating and $\mathrm{Si}$ addition to the matrix) to reduce the $\mathrm{U}-\mathrm{Mo} / \mathrm{Al}$ interaction layer growth during the TT is discussed in this section. At $500^{\circ} \mathrm{C}$, the external part of the IDL remains enriched in $\mathrm{O}$ even if this element has probably partly diffused in Al matrix. At $670^{\circ} \mathrm{C}$, the duplex structure of IDL is less obvious (in the meat centre). Close to the cladding, some areas enriched in $\mathrm{O}$ remain contiguous even in case of full $\mathrm{U}-\mathrm{Mo} / \mathrm{Al}$ interaction: $\mathrm{O}$ enriched zones can be considered as a marker of the previous U-Mo particle (or IDL) location.

Full diffusion of $\mathrm{Si}$ from the matrix into the internal part of the IDL has been observed. Such an almost homogeneous repartition of $\mathrm{Si}$ inside an IDL at $500^{\circ} \mathrm{C}$ has to our knowledge not been reported in literature. At higher temperatures $\left(670^{\circ} \mathrm{C}\right)$, in the fuel meat centre, its behaviour has not strongly evolved any further. Towards the outer sample part, in fully interacted zones, $\mathrm{U}_{\mathrm{x}} \mathrm{Si}_{\mathrm{y}}$ rich compounds have formed with a low $\mathrm{Al}$ and Mo content.

At $670^{\circ} \mathrm{C}$, oxide and Si cannot prevent $\mathrm{U}-\mathrm{Mo} / \mathrm{Al}$ interaction.

\subsubsection{U-Mo particles}

It is known that in-pile irradiation stabilises the $\gamma \mathrm{U}$-Mo structure [48]. Annealing in-pile irradiated fuel at $500{ }^{\circ} \mathrm{C}$ has induced the destabilisation of the metastable $\gamma$-U-Mo phase. This has been shown first by XRD. Moreover cracks (intergranular and/or circumferential) within U-Mo particle cores have appeared. Circumferential cracks may be obtained during the sample cooling step.

At $670^{\circ} \mathrm{C}$, cells inside U-Mo particles are not observable anymore using X-ray maps and cracks inside U-Mo particles do present the same morphology and size.

\subsection{Interpretation of Xe release kinetics}

Both fission products and microstructures have been investigated after TT at 500 and $670{ }^{\circ} \mathrm{C}$. Based on these studies, origins for each FG release peaks observed during the experiment are proposed (see Table 5).

At temperatures below $400^{\circ} \mathrm{C}, 2.4 \%$ of the total fission gas release has been observed (see Table 2). In this case, the fission gas release may have happened out of volumes close to the sample surfaces.

Between $400{ }^{\circ} \mathrm{C}$ and $500{ }^{\circ} \mathrm{C}, 13.8 \%$ of the total FG release occurs. These fission gases are believed to be mainly located at matrix/IDL interface (e.g. in the large porosities), in the external part of the IDL or even in the matrix. Since IDLs and matrix are no longer in contact, and assuming an interconnection of the porosities found at these interfaces with each other and with the free volume, FG can be released outside the samples. Even if the IDL should have recrystallized at $500^{\circ} \mathrm{C}$, the $\mathrm{FG}$ diffusion towards the IDL/matrix interface does not seem to have increased significantly. The FG diffusion from the particle core to the IDL has been shown to occur especially at meat/cladding interfaces but is not believed to represent a significant enough amount. Moreover, it is assumed that cracks within particle cores are not linked to free volumes. Moreover the Xe weight fraction measured using EPMA on the sample thermally annealed up to $500{ }^{\circ} \mathrm{C}$ shows that the Xe quantity remaining in this sample is very low compared to the FG released fraction. Two hypotheses may explain this difference. Firstly and as already mentioned, Xe weight fraction in U-Mo cores has been underestimated because of sample preparation. A dedicated study of bubble size in these particle cores would be very useful to definitely confirm this proposition. Secondly, a large amount of Xe is present at the IDL/matrix interfaces in many places inside the meat (especially in the centre); however these porosities would not be connected to the free volumes. Additional experimental work and modelling are here clearly needed to get a definitive determination of the location from which fission gas release has occurred.

In the $500-670^{\circ} \mathrm{C}$ temperature range, $57 \%$ of the total fission gas release has been observed. This release is attributed to the FG inside U-Mo particles close to the cladding regions. This is due to total U-Mo/Al interaction in these zones. Note that some FG gas has still been found in this area: the fission gas release is not complete.

For temperatures above $670^{\circ} \mathrm{C}$, an increasing amount of U-Mo particles and IDLs are affected by the U-Mo/Al interaction process and fission gases trapped in this interaction are also released. Fission gas release ( $26.8 \%$ of the total amount) occurs until the whole sample (including the meat centre) is affected by interaction processes.

\section{Conclusions}

The goal of this paper is to investigate the fission gas (FG) behaviour in atomised $\mathrm{U}-\mathrm{Mo} / \mathrm{Al}(2.1 \mathrm{wt}$.\% $\mathrm{Si})$ nuclear fuels. The particles were protected with a $1 \mu \mathrm{m}$ thick oxide layer. Previous experiments have demonstrated the better in-pile irradiation behaviour (with respect to the pure $\mathrm{U}-\mathrm{Mo} / \mathrm{Al}$ case) of fuel plates optimised with either Si added to the matrix, or U-Mo particles protected with an oxide layer. Microstructural analyses done here on in-pile irradiated oxidised $\mathrm{U}-\mathrm{Mo} / \mathrm{Al}(2.1 \mathrm{wt}$.\% $\mathrm{Si})$ fuels taken from 
the IRIS4 experiment showed that the positive effects of both solutions are not added. It is very likely that the presence of an oxide layer has reduced the Si diffusion kinetics towards U-Mo particles. This is visualised by the growth of a typical $\mathrm{U}-\mathrm{Mo} / \mathrm{Al}$ interdiffusion layer (IDL) around the particles which has not been delayed enough. It is well known that this Si diffusion can (besides irradiation) also be thermally activated. A striking illustration of this phenomenon has been obtained after thermal treatment up to $500^{\circ} \mathrm{C}$ of the inpile irradiated fuel plate: Si has fully diffused towards the IDL.

Thermal treatments (TT) on in-pile irradiated fuel plate revealed two major FG release peaks around $500{ }^{\circ} \mathrm{C}$ and $670{ }^{\circ} \mathrm{C}$. While the interpretation regarding the $\mathrm{FG}$ source giving rise to the peak at $500{ }^{\circ} \mathrm{C}$ will require a confirmation, it is clear that the second peak (at $670^{\circ} \mathrm{C}$ ) is due to a strong interaction between U-Mo particles and matrix close to the cladding.

Further understanding of fission gas behaviour inside irradiated $\mathrm{U}-\mathrm{Mo} / \mathrm{Al}$ samples would require more work. For example, the modelling of these fission gas release curves should be particularly fruitful.

\section{Acknowledgments}

Authors do acknowledge the MERARG team for their experimental work (CEA) and F. Charollais, J. Noirot and finally B. Kapusta for their advices and comments. This study was supported by a combined Grant (FRM0911) of the Bundesministerium für Bildung und Forschung (BMBF) and the Bayerisches Staatsministerium für Wissenschaft, Forschung und Kunst (StMWFK).

\section{References}

[1] J.L. Snelgrove, G.L. Hofman, C.L. Trybus, T.C. Wiencek, in: Proceedings of the 19th International Topical Meeting on Reduced Enrichment for Research and Test Reactors (RERTR), Seoul, South Korea, 1996.

[2] P. Lemoine, J.L. Snelgrove, N. Arkhangelsky, L. Alvarez, in: Proceedings of the 8th International Topical Meeting on Research Reactor Fuel Management (RRFM), Munich, Germany, 2004.

[3] G.L. Hofman, M.R. Finlay, Y.S. Kim, in: Proceedings of the 26th International Topical Meeting on Reduced Enrichment for Research and Test Reactors (RERTR), Vienna, Austria, 2004.

[4] F. Huet, J. Noirot, V. Marelle, S. Dubois, P. Boulcourt, P. Sacristan, S. Naury, P. Lemoine, in: 9th International Topical Meeting on Research Reactor Fuel Management (RRFM), Budapest, Hungary, 2005.

[5] S. Van den Berghe, W. Van Renterghem, A. Leenaers, J. Nucl. Mater. 375 (2008) 340-346.

[6] J. Gan, D.D. Keiser, D.L. Wachs, A. Robinson, B.D. Miller, T.R. Allen, J. Nucl. Mater. 396 (2010) 234-239.

[7] J. Gan, D.D. Keiser Jr., B.D. Miller, A.B. Robinson, J.F. Jue, P. Medvedev, D.M. Wachs, J. Nucl. Mater. 424 (2012) 43-50.

[8] A. Leenaers, S. van den Berghe, W. van Renterghem, F. Charollais, P. Lemoine, C. Jarousse, A. Röhrmoser, W. Petry, J. Nucl. Mater. 412 (2011) 41-52.

[9] O.A. Golosov, V.B. Semerikov, A.E. Teplykh, M.S. Lyutikova, E.F. Kartashev, V.A. Lukichev, in: 11th International Topical Meeting on Research Reactor Fuel Management (RRFM)/IFDWG, Lyon, France, 2007.

[10] J. Lamontagne, Y. Pontillon, E. Esbelin, S. Béjaoui, B. Pasquet, P. Bourdot, J.M. Bonnerot, J. Nucl. Mater. 440 (2013) 366-376.

[11] M. Ripert, S. Dubois, J. Noirot, P. Boulcourt, P. Lemoine, S. Van den Berghe, A Leenaers, A. Rohrmoser, W. Petry, C. Jarousse, Transactions of RRFM-2008, Hamburg, Germany, March 2-5, 2008.

[12] A. Izhutov, V. Alexandrov, A. Novosyolov, V. Starkov, A. Sheldyakov, V. Shishin, V. Iakovlev, I. Dobrivka, A. Vatulin, G. Kulakov, V. Suprun, in: Proceedings of the 32nd International Topical Meeting on Reduced Enrichment for Research and Test Reactors (RERTR), Lisbon, 2010.

[13] S. Dubois, H. Palancher, F. Mazaudier, P. Martin, C. Sabathier, M. Ripert, P. Lemoine, C. Jarousse, M. Grasse, N. Wieschalla, W. Petry, in: Proceedings of the 28th International Topical Meeting on Reduced Enrichment for Research and Test Reactors (RERTR), Cape Town, South Africa, 2006
[14] Y.S. Kim, G.L. Hofman, H.J. Ryu, J. Rest, in: Proceedings of the 32nd International Topical Meeting on Reduced Enrichment for Research and Test Reactors (RERTR), Boston, 2005.

[15] G.L. Hofman, Y.S. Kim, H.J. Ryu, J. Rest, D.M. Wachs, M.R. Finlay, in: Proceedings of the 10th International Topical Meeting on Research Reactor Fuel Management (RRFM), Sofia, Bulgaria, 2006

[16] M. Ripert, V. Marelle, X. Iltis, H. Palancher, Ch. Valot, F. Charollais, M.C. Anselmet, X. Tiratay, P. Lemoine, S. van den Berghe, A. Leenaers, C. Jarousse, in: Proceedings of the 15th International Topical Meeting on Research Reactor Fuel Management (RRFM), Rome, Italy, 2011.

[17] A. Leenaers, S. Van den Berghe, J. Van Eyken, E. Koonen, F. Charollais, P. Lemoine, Y. Calzavara, H. Guyon, C. Jarousse, D. Geslin, D. Wachs, D. Keiser, A. Robinson, G. Hofman, Y.S. Kim, J. Nucl. Mater. 441 (2013) 439-448.

[18] Y.S. Kim, G.L. Hofman, A.B. Robinson, in: Proceedings of the 13th International Topical Meeting on Research Reactor Fuel Management (RRFM), Vienna, Austria, 2009.

[19] D.D. Keiser, Y.F. Yue, B. Yao, E. Perez, Y.H. Sohn, C.R. Clark, J. Nucl. Mater. 412 (2011) 90-99.

[20] C.K. Kim, J.M. Park, H.J. Ryu, Nucl. Eng. Technol. 39 (2007) 617-626.

[21] J.M. Park, H.J. Ryu, K.H. Kim, D.B. Lee, Y.S. Lee, J.S. Lee, B.S. Seong, C.K. Kim, M. Cornen, J. Nucl. Mater. 397 (2010) 27-30.

[22] H. Palancher, A. Bonnin, V. Honkimaki, H. Suhonen, P. Cloetens, T. Zweifel, R. Tucoulou, A. Rack, M. Voltolini, J. Appl. Crystallogr. 45 (2012) 906-913.

[23] F. Charollais, M. Ripert, M.C. Anselmet, P. Boulcourt, X. Tiratay, P. Lemoine, C. Jarousse, in: Proceedings of the 13th International Topical Meeting on Research Reactor Fuel Management (RRFM) Vienna, Austria, 2009.

[24] B. Kapusta, C. Sainte-Catherine, X. Averty, M. Scibetta, G.M. Decroix, M. Rommens, in: Proceedings of the 9th IGORR Conference, Sydney, Australia, March 24-28, 2003.

[25] M. Wintergerst, N. Dacheux, F. Datcharry, E. Herms, B. Kapusta, J. Nucl. Mater. 393 (2009) 369-380.

[26] Y.S. Kim, in: Comprehensive nuclear Materials, 2012, pp. 391-421.

[27] H. Palancher, A. Bonnin, V. Honkimäki, T. Buslaps, M. Grasse, B. Stepnik, T. Zweifel, J. Alloys Compd. 527 (2012) 53-65.

[28] D.D. Keiser, A.B. Robinson, J.F. Jue, P. Medvedev, D.M. Wachs, M.R. Finlay, J. Nucl. Mater. 393 (2009) 311-320.

[29] X. Iltis, F. Charollais, M.C. Anselmet, P. Lemoine, A. Leenaers, S. Van den Berghe, E. Koonen, C. Jarousse, D. Geslin, F. Frery, H. Guyon, in: Proceedings of the 32th International Meeting on Reduced Enrichment for Research and Test Reactors (RERTR), Lisbon, Portugal, 2010.

[30] H. Palancher, A. Bonnin, F. Charollais, P. Lemoine, S. van den Berghe, A. Leenaers, E. Koonen, B. Stepnik, C. Jarousse, Y. Calzavara, H. Guyon, in: Proceedings of the 16th International Topical Meeting on Research Reactor Fuel Management (RRFM), Prague, Czech Republic, 2012.

[31] R. Jungwirth, H. Palancher, A. Bonnin, C. Bertrand-Drira, C. Borca, V. Honkimäki, C. Jarousse, B. Stepnik, S.H. Park, X. Iltis, W. Schmahl, W. Petry, J. Nucl. Mater. 438 (2013) 246-260.

[32] X. Iltis, Internal Report NT LCU 09-020, CEA, Cadarache, France.

[33] Ch. Valot, I. Aubrun, J. Lamontagne, Th. Blay, L. Brunaud, P. Delion, N. Monchalin, M. Ripert, F. Charollais, M.C. Anselmet, P. Lemoine, in: Proceedings of the 33th International Topical Meeting on Reduced Enrichment for Research and Test Reactors (RERTR), Santiago de Chile, 2011.

[34] M. Ripert, F. Charollais, M.C. Anselmet, X. Tiratay, P. Lemoine, in: Proceedings of the 31st International Topical Meeting on Reduced Enrichment for Research and Test Reactors (RERTR), Beijing, China, 2009.

[36] H.J. Ryu, J.M. Park, K.H. Lee, B.O. Yoo, Y.H. Jung, Y.J. Jeong, Y.S. Lee, in: Proceedings of the 16th International Topical Meeting on Research Reactor Fuel Management (RRFM), Saint Petersburg, Russia, 2013, pp. 105-113.

[37] Y. Pontillon, L. Desgranges, A. Poulesquen, J. Nucl. Mater. 385 (2009) 137-141.

[38] P. Menegon, L. Desgranges, Y. Pontillon, A. Poulesquen, J. Nucl. Mater. 378 (2008) $1-8$

[39] Y.S. Kim, in: Comprehensive Nuclear Fuel Materials, 2012, pp. 391-421.

[40] J. Lamontagne, L. Desgranges, C. Valot, J. Noirot, T. Blay, I. Roure, B. Pasquet, Microchim. Acta 155 (2006) 183-187.

[41] A. Bonnin, H. Palancher, V. Honkimäki, R. Tucoulou, Y. Calzavara, C.V. Colin, J.F. Bérar, N. Boudet, H. Rouquette, J. Raynal, C. Valot, J. Rodriguez-Carvajal, Zeit. Kristall. Proc. 1 (2011) 29-34.

[42] P.E. Repas, R.H. Goodenow, R.F. Hehemann, Trans. ASM 57 (1964) 150-163.

[43] A. Leeaners, F. Joppen, S. van den Berghe, J. Nucl. Mater. 394 (2009) 87-94.

[44] G. Rummel, T. Zumkley, M. Eggersmann, K. Freitag, H. Mehrer, Z. Metallkd 85 1995) 122-130.

[45] H.J. Ryu, Y.S. Han, J.M. Park, S.D. Park, C.K. Kim, J. Nucl. Mater. 321 (2003) 210220.

[47] Y.S. Kim, G.L. Hofman, J.S. Cheon, J. Nucl. Mater. 436 (2013) 14-22.

[48] M.L. Bleiberg, J. Nucl. Mater. 1 (1959) 182-190. 